\title{
The Honourable Merchant- Foundations and Guidelines Steering All CCI Work
}

\author{
Gabriele Lüke and Ulrich Pfaffenberger
}

The honourable merchant has always been the ethical point of reference for the work of the CCIs; as a cross-cutting issue, it also touches on all other areas. This chapter translates the model of the honourable merchant into modern times and into practical work. It begins with an in-depth interview with Gerti Oswald, Chief Executive of the Association of Bavarian Chambers of Commerce and Industry and responsible for CSR (Corporate Social Responsibility) at the CCI for Munich and Upper Bavaria. She explains the idea of the honourable merchant and its special significance for today. Afterwards, an overview will show how the CCI Munich carries the mission statement into the companies, namely with the help of a staff unit reporting directly to the primary management team, which was established six years ago. The implementation of the mission statement also envisages that the Munich Chamber of Commerce and Industry clarifies which political framework conditions are necessary for responsible business - in order to then stand up for the interests of the members in the best possible way and support them accordingly. In addition, the CCI empowers its members with guidelines and instructions to better embed the mission statement in their companies. This chapter also provides examples of this. Finally, mediation and arbitration, two formats of out-of-court dispute resolution, are presented. Not taking a dispute to court immediately, but resolving it out of court first, is also the highest expression of honourable commercial behaviour for the CCI. The chapter ends with six portraits of businessmen and women who uphold the values of the honourable merchant.

\footnotetext{
G. Lüke $(\bowtie)$

Konturprogramm - Unternehmenskommunikation, Munich, Germany

e-mail: g.lueke@konturprogramm.de

U. Pfaffenberger

Journalist, Pfaffing, Germany

e-mail: upf@ulrich-pfaffenberger.com

(C) The Author(s) 2021

E. Sasse and A. Habisch (eds.), The German Chambers of Commerce and Industry,

Practical Wisdom for Sustainable Organizations,

https://doi.org/10.1007/978-3-030-70799-6_8
} 
- Interview with Gerti Oswald: The honourable merchant-providing orientation sustainably

- The CCI brand identity - putting ethics into practice

- Corporate Social Responsibility (CSR)—bringing the honourable merchant into business

- CSR studies - identifying and fulfilling members' needs

- CSR guidelines - helping companies on their path towards responsible business practices

- CSR within the CCI-more responsibility together

- Out-of-court dispute resolution - charting a shorter route to a win-win situation

- Portraits

\section{The Honourable Merchant-Providing Orientation Sustainably}

The foundation and guideline for the work of the CCI is the model of the honourable merchant. He stands for fair, sustainable and responsible business. An interview with Gerti Oswald, Managing Director of the Association of Bavarian Chambers of Commerce and Industry and head ofCSR (Corporate Social Responsibility) of the CCI for Munich and Upper Bavaria.

Gerti Oswald, Photo Credit: CCI for Munich and Upper Bavaria/Goran Gajanin_Das Kraftbild

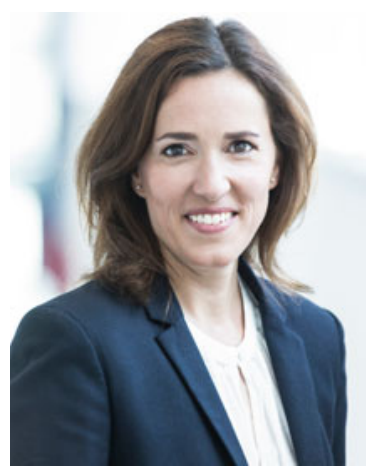

The Chambers Of Commerce and Industry has to work for the preservation of the decency and morals of respectable business people. This is stated in the CCI law. This formulation sounds quite old-fashioned, to be honest...

The honourable merchant is essential to the understanding of the chamber of commerce and industry movement. He has always shaped our work. The model of the honourable merchant originated in the Middle Ages and is therefore indeed very 
old, but certainly not old-fashioned. On the contrary: the idea is absolutely timeless, even more modern than ever.

What exactly does the mission statement stand for?

The honourable merchant began as a generally unwritten agreement among businessmen to treat each other fairly: An honourable merchant seals a deal with a handshake and is honest and reliable. For centuries, the guiding principle was the only guarantee for orderly trade as opposed to robbery. At the same time, an honourable merchant always treated his employees fairly and did a great deal for society.

How would you translate the honourable merchant into the present day?

The modern honourable merchant acts sustainably and responsibly in a comprehensive economic, social and ecological sense. He wants his company to grow - but not at the expense of others, his employees or partners, society or the environment. At the same time, he acknowledges that such behaviour also represents an entrepreneurial opportunity to strengthen his company's competitiveness, innovation and sustainability. The management approach that expresses the model of the honourable merchant and his values particularly well is Corporate Social Responsibility-CSR. It is this approach that we as CCIs strive to establish in the operational practice of companies.

And the handshake is still enough for respectable business people today?

In principle, yes, if two business people who are guided by these values shake hands, the transaction should still be essentially sealed today. But the economy and the law have also become very complex at the same time. It would therefore be negligent to forego well-structured contracts.

If you look at the development of the world as well as responsible and sustainable business, the guiding principle of the honourable merchant is ultimately also the imperative of the hour?

Absolutely. In fact, we are facing complex structural upheavals. Whether fair globalisation, curbing climate change and resource consumption, digitisation or poverty reduction - business can, must and wants to make a contribution locally but also globally. Otherwise, we will not be able to master these challenges. Taking responsibility in this sense secures the future - and ultimately the economic foundations of our society. And not only for ourselves at this specific point in time but also worldwide and for future generations. And this is only possible with "honourable merchants".

The legislator had included the model of the honourable merchant into the CCI law as early as 1956. Why does this still fit today?

The CCIs stand for economy in self-governance-the economy should organise itself, develop of its own accord, and represent its interests. But this self-governance also needs anchor points. These are laid out in the model of the honourable merchant. First and foremost the legislator offers orientation with this model. In doing so, it falls back on a model that has existed for a long time and that the economy shaped itself, that is firmly anchored in the collective consciousness of companies and that 
has proven itself time and again. At the same time, the mission statement also makes demands on the economy: namely to look beyond one's own horizon and not just to strive for personal advantage. Thus, guidance in the form of the honourable merchant is not only beneficial to the economy itself, but to society as a whole.

Does this also mean that the values of the honourable merchant run through all of the CCI's work: the tasks assigned by the state, company promotion and the representation of overall interests?

The mission statement is the foundation and guideline for our work. It should always be present in all areas of activity and provide impetus.

How do the companies themselves contribute to the implementation and further development of the mission statement in the general assembly and the regional committees?

The impetus to make the mission statement more visible came from the business community. We had a financial and economic crisis in Germany 10 years ago. The media and the population took companies, their part in the crisis, and their failures to act, to court. The economy had to answer many questions: How responsible am I really in my business? How do I deal with suppliers, partners, employees, competitors? The time was right to recall the model of the honourable merchant, to take it more seriously again, and to revive it. The decisive impulse was given by Professor Dr. Dr. h.c. mult. Erich Greipl, who himself was both a successful entrepreneur and former president of the Munich Chamber of Commerce and Industry. In the meantime, we as the Munich Chamber of Commerce and Industry, together with the honorary office on site in Munich and Upper Bavaria, in Bavaria itself and throughout Germany, are working to ensure that the honourable merchant increasingly becomes the blueprint for all business decisions.

Does it sometimes come to controversial debates, contradictions and disputes between the primary and honorary office or among the companies themselves as to what the honourable merchant means and how it should be implemented?

Discussions are part of the process and we meet them as they arise. But it is true that what is good in terms of social responsibility can initially mean costs or effort on behalf of an individual company. This is precisely why the discussion is so important. CCI work does not mean simply showing the economy the easiest way, but the most responsible way - and that can be rocky at first. Companies have to deal with new challenges constantly. Here, we have to find as many points of intersection as possible.

How deeply is the concept of the honourable merchant anchored in business practice?

Our surveys on this topic, which we repeat regularly, show that most entrepreneurs attach great importance to responsible business practices. Many have already integrated CSR activities into their corporate culture and strategy. In particular, they often approach ecological issues very consistently. Another very interesting result of the surveys for us was that the implementation of the mission statement is mainly based on a person's own attitude and values. 
After all, what do the companies gain from committing to the mission statement?

They don't just do something for their good conscience or for their image. They reach new customers, namely those who are looking for more responsibility and sustainability-and these customers are growing in numbers all the time. A sustainable and responsible corporate strategy helps to contain risks, save costs, open up new markets and increase innovative strength. With this strategy, companies gain and retain employees more easily, which is becoming increasingly important in times of a shortage of skilled workers and demographic change, which we have in Germany. After all, sustainability is now also the hallmark of an attractive employer, and employees are increasingly attaching importance to it. And last but not least, they are prepared for future, possibly stricter sustainability legislation.

You spoke of the inner attitude and values. But at the same time, civic society and politics are increasingly demanding more responsibility of business?

Correct. Within the framework of Agenda 2030, the United Nations has adopted 17 sustainability goals, the so-called Sustainable Development Goals - or SDGs for short - there are also the UN guiding principles on business and human rights, the EU regulation on conflict minerals or the EU action plan for sustainable growth, and at the same time many national laws and frameworks, some of which are a result of this.

Speaking of which, don't more and more laws and regulations contradict entrepreneurial freedom?

I would answer with this scenario: without laws and regulations, it is much easier for those who act sustainably to be overtaken by those who do not yet act sustainably - because the latter can produce more cheaply, for example. That is why the companies themselves also want a uniform legal framework, a level playing field for everyone-preferably worldwide. Nonetheless, we are committed to ensuring that these laws and regulations remain manageable and pragmatic for companies and that the bureaucratic burden does not become too great. Bureaucracy must not be allowed to stifle the goodwill of businesses with the consequence that companies only do the bare minimum. In our dealings with politicians, we therefore advocate not only a uniform legal framework but also incentives such as tax incentives. Voluntary action alone is not enough either.

What role does the consumer play? At present, sustainably produced goods are more expensive than conventional goods in Europe. Not everyone can afford these. Consumers thus turn to non-sustainable cheap T-shirts, for example.

That is correct. That's why it is so important that the legal framework conditions are promoted throughout Europe and worldwide. Then producers will not be able to avoid sustainable production and even cheap T-shirts will still meet minimum standards. 
Let us go into practice. What instruments do you provide your member companies with?

We provide information in publications, have drawn up practice-oriented guidelines, point out best practice examples from the various sectors, organise the major Bavarian CSR Day once a year and offer companies further training to become CSR Managers at the CCI Academy. And just recently we founded the CCI Committee for Corporate Responsibility. Here and also at our events, companies can exchange information and learn from each other-which they do intensively. We also deliberately work across departments: our Environmental and Energy Department, which is responsible for energy saving, resource conservation or environmental management, or the Specialist Department, which deals with the compatibility of family and career, company health or diversity, also play a key role in the issue of sustainability. In this way, together we increase the practical CSR knowledge in the companies across the departments.

Now this book promotes the CCI as an organisation. How do you convince readers in the target countries of the concept of the honourable merchant?

The Bavarian Chambers of Commerce and Industry celebrated their 175th anniversary in 2018, and we have given the celebrations the motto "Ideas have strength". One of these powerful ideas is the model of the honourable merchant. The concept changes companies makes them resilient and more successful. So the best way to advertise the mission statement is for companies to benefit from its implementation ...

And what does it look like on the inside? Does the mission statement also apply to the primary office?

Of course. We as the Chamber of Commerce and Industry for Munich and Upper Bavaria set out some time ago on this path. We have set up our own CSR department directly within the primary management team, which also promotes the issue internally. For the 2018 financial year, we prepared our first sustainability report taking stock of the situation, developing key figures and showing how we, as the largest chamber of commerce and industry in terms of members, are contributing to the future viability of companies with our activities.

Ms. Oswald, thank you for the interview.

\section{The CCl Brand Identity-Putting Ethics into Practice}

The German Chambers of Commerce and Industry have also further developed the "CCI" brand on the initiative of the Bavarian Chambers of Commerce and Industry. Since 2015, the brand identity has been the commitment "Together we take responsibility". 
Developing a common commitment is one thing, but how do you put it into practice? All 79 German CCIs were therefore called upon to adapt the new brand identity for themselves and to fill it with life. The CCI for Munich and Upper Bavaria, as Germany's largest CCI, has set up a strategic process that will result in a roadmap entitled "Economy and business for the Future" and a sustainability report - and this is far from over.

\section{Creating Value}

For Manfred Göß1, Chief Executive of the Chamber of Commerce and Industry for Munich and Upper Bavaria, the process comes at just the right time: "We are focusing even more strongly on our mission statement of the honourable merchant and are reflecting on our values and what makes us what we are. In this way, we want to offer a source of orientation to our member companies, our volunteers and our employees. We act responsibly towards each individual, our home region of Upper Bavaria and society as a whole.

The CCI's brand identity is the starting point for a change process. It serves as a vision, should provide solid guidance and thus contribute to the future viability of the company. Because even if (or precisely because) Upper Bavarian companies are doing quite well, the question arises for them and their environment of how to deal with the major challenges - from climate change to digitalisation - in such a way that sustainable development is strengthened: for the economy itself but also for society, for the region and not least for the future of all of us.

\section{Business for the Future}

The belief that everyone profits when the economy and businesses are doing well has noticeably faltered. It is not for nothing that the European Union, with its concept of Corporate Social Responsibility (CSR), is also calling for more responsibility from companies for the effects of their actions. After all, not only internationally competitive location conditions but also an intact environment and a stable society are prerequisites for long-term successful economic activity. At the CCI for Munich and Upper Bavaria, which just celebrated its 175th anniversary, the change in perspective is expressed in the new slogan: "Economy and business for the future".

Associated with this is a clear commitment to 390,000 member companies, 12,000 volunteers, 450 employees and six locations: "Together we are strengthening sustainable development - for the economy in the region and the society of tomorrow". 


\section{Guideline for Daily Action}

Four brand attributes underpin the brand identity: reliable for the economy and business, rooted in the region, responsible for society and forward-looking for the future. This is what the CCI is all about, this is how it acts. And it is with this understanding of its role that it continues to perform its tasks: representing overall interests, organising the economy itself and promoting companies - the foundation and guiding principle of the honourable merchant.

The members of the steering committee and the general assembly of the Chamber of Commerce and Industry for Munich and Upper Bavaria were part of the process from the very beginning and continue to accompany it. The brand identity is also discussed with voluntarily engaged entrepreneurs in the regional and specialist committees. All CCI employees are also working together to implement the brand identity in the day-to-day work. The brand identity is at the forefront of the CCI's future programme, consisting of eight fields of action with concrete, measurable objectives as a target. Sustainability is thus a continuous process everyone is working on together.

\section{Together We Take Responsibility!}

For the economy and business: We support companies, bundle interests with the participation of our members and take a stand.

For the region: We embody our holistic mission with the goal of sustainable development for our region and beyond.

For society: We empower people, enable participation and guarantee stability and fairness in the social market economy.

For the future: We provide impetus and are committed to economic progress that contributes to the well-being of present and future generations.

\section{Corporate Social Responsibility-Bringing the Honourable Merchant into Businesses}

To work for the preservation of the morals and decency of the honourable merchant - the CCI law gives this task to the CCIs. With a wide range of activities, they translate the mission statement into support and benefits for companies.

The honourable merchant is a central figure for the CCI organisation. With his values, all the good qualities of a businessman are bundled: The honourable merchant is honest, fair, incorruptible, and reliable. He can be trusted. He treats his employees, partners, suppliers and the environment decently and is committed to society, works responsibly and sustainably. Even in times pre-dating the Chambers, he set the direction - his code of conduct is a kind of first ethical set of rules for commercial conduct, an unwritten agreement to which everyone nevertheless adheres. 


\section{Growing Challenges for Respectable Business People}

For about 10 years now, the mission statement has been experiencing a renaissance. And that's a good thing because the challenges facing the economy are growingdue to megatrends such as digitalisation and globalisation, climate change and migration movements. These challenges are accompanied by regular UN appeals and guidelines but also by concrete regulatory requirements from the EU or sovereign states, which demand that companies act more responsibly with regards to the environment, employees and society. These include, for example, the 17 Sustainable Development Goals of the United Nations, which are reflected in the German Sustainability Strategy, albeit a rather non-binding one, or the National Action Plan for Business and Human Rights, which stems from the UN guidelines, the obligation to report on CSR, the EU Conflict Minerals Regulation or the EU Action Plan for Sustainable Growth.

\section{Management Approach-Corporate Social Responsibility}

The Chamber of Commerce and Industry for Munich and Upper Bavaria has anchored the model of the honourable merchant deep in its DNA and, together with all Bavarian Chambers of Commerce and Industry, also supports companies through a variety of activities.

The management approach of Corporate Social Responsibility plays a key role in this. It is the transmission belt with which companies can install the ideas of social, ecological and economic sustainability in their companies. It enables them to create sustainable structures, both internally and with regard to partner companies, to establish responsibilities, to train staff and thus to achieve fair, sustainable corporate management. Besides the values of the honourable merchant, it is this practical management approach which the Chamber of Commerce and Industry promotes and which it carries into the companies.

The CSR activities of the CCI for Munich and Upper Bavaria at a glance:

- Staff unit-honourable merchant: In order to be able to communicate approaches to the outside world, an organisation needs a unit that takes care of the topic. In order to do justice to the special importance of the topic, in 2010 the CCI for Munich and Upper Bavaria not only created a department but also a staff unit, which reports directly to the primary management team. With three employees, the CSR topic is extensively taken care of here-from information about events to political positions.

- CCI Committee "Corporate Responsibility": Founded in the summer of 2018 as a working group with more than 40 member companies under the chairmanship of the Munich entrepreneur and CCI Vice President Kathrin 
Wickenhäuser-Egger (see also portraits at the end of this chapter), it was upgraded to a CCI Committee by resolution of the CCI general assembly in December 2018. Its aim: to strengthen sustainability as a model for future-oriented development, to contribute to the implementation of the UN Agenda 2030 in the region and to give responsible business a voice in the political and social debate. The committee thus actively contributes to the implementation of the brand identity"Together we take responsibility".

- Bavarian CSR Day: The Bavarian CSR Day has already taken place six times. It is a joint event of all Bavarian Chambers of Commerce and Industry. The first event was held in 2013, with around 300 participants from all over Bavaria coming to Munich. The Bavarian CSR Day is the largest Bavarian networking event on the subject of CSR. On the agenda in 2017 were the UN Agenda 2030 with its 17 Sustainable Development Goals (SDGs). In 2018, CSR Day focused on the topic of digitisation and sustainability. In lectures and interactive thematic forums, experts from business, politics and civil society discussed how the potential of digitisation can be raised to achieve a turnaround in sustainability.

- Stocktaking with studies and surveys: What is the position of companies on the current challenges? What are they already doing? What do they need? In order to tailor materials, events and services precisely to companies, the Bavarian Chambers of Commerce and Industry keeps asking the necessary questions. The results of the studies not only provide information on the content of events, positions or instructions for action. They also encourage primary and voluntary members of staff to continue along the CSR path.

- Empowerment through guidance for action: In order to promote CSR in companies, the Bavarian Chambers of Commerce and Industry have developed guidelines and aids that provide companies with practical introductions to CSR management or individual CSR areas. These include guidelines on value-based management for small and medium-sized enterprises or fair supply chain management.

- Political and civil society cooperation: To increase the impact, the Munich Chamber of Commerce and Industry (CCI Munich) works together with the other Bavarian Chambers of Commerce and Industry and with other partners. For example, guidelines for action were developed in cooperation with the Bavarian Ministry of Labour, within the framework of the Bavarian Environmental Pact initiated by the Ministry of the Environment, or with the civic society initiative "Global Compact". The cooperation also includes support for the "Gute Geschäfte" marketplace. This is an offer from the Munich-based volunteer organisation "Tatendrang". Tatendrang places volunteers who want to get involved in society with social organisations. On the "Gute Geschäfte" marketplace, these initiatives are in turn linked to companies that would like to offer their employees corporate volunteering opportunities. The Chamber of Commerce and Industry for Munich and Upper Bavaria supports the marketplace as a cooperation partner and provides the necessary facilities. 
- Representation of overall interests: If the legislator drafts new regulations (CSR reporting requirements, National Action Plan for Business and Human Rights, etc.), the CCI comments on these during the legislative process after consultation from the perspective of the companies.

- Out-of-court settlement of disputes: It is impossible to prevent disputes within and between companies. State courts, the CCI argues, should always be the last resort. For it is part of the self-image of a self-organising economy and the model of the honourable merchant that, in the event of a dispute, independent solutions are sought first, independent of state authority. The Chamber of Commerce and Industry for Munich and Upper Bavaria offers several formats, including a conciliation board for competition disputes, business mediation, mediation between trainees and trainers, arbitration reports and arbitration. This makes it a pioneer in the CCI landscape; the offers have been available since the 1990s.

\section{CSR Studies-Identifying and Fulfilling Members' Needs}

It is important for the Munich Chamber of Commerce and Industry to know what companies think about responsible business and what they need to become better and better at it. That is why the CCI regularly asks through studies and surveys in order to then empower the companies and to carry demands into politics

One of the basics of the CCI's work is to maintain close contact with the companies in all areas of activity and to know their opinions and wishes. This feedback appears to be particularly important when legal requirements or an assertive new attitude calls established behaviour into question and new standards are to be introduced in companies - as is the case in the field of CSR.

With this in mind, the Chamber of Commerce and Industry for Munich and Upper Bavaria repeatedly asks companies in studies and surveys and takes stock in order to derive recommendations for action both for the companies themselves and for politics. In addition, it bases its own service and information offers, with which it supports companies, on the results. In this way, the CCI is involved in a process that enables companies, as well as politics and society, to achieve greater sustainability, and is helping to drive it forward. This is illustrated by two examples.

\section{Study on responsible management in Bavaria - exemplifying values in companies}

For almost 10 years now, the Bavarian Chambers of Commerce and Industry have been reactivating the model of the honourable merchant. In 2018, they asked: What is the status of "responsible management" in Bavarian companies? What drives the companies? What are they already doing? And what do they need so that they can operate even more sustainably, responsibly - and successfully in the future? 


\section{The key results at a glance:}

- Personal attitude and business advantages: For the majority of companies, values and personal attitude are the basis for responsible business. The companies want to positively influence the environment and society with responsible approaches. At the same time, the companies know that responsible management also benefits them in business terms. They also cite employee satisfaction, employer attractiveness and a better corporate image as drivers for their commitment.

- Environmental protection as a mega topic: For the future, environmental issues in particular are at the top of the agenda. But companies have also recognised the importance of digitisation for sustainability. The vast majority of the companies surveyed are already active in climate protection - in buildings, in production processes and in the areas of transport and mobility. Just under half of the companies are concerned with environmental and social standards in the supply chain.

- Desire for reliable framework conditions: Responsibility and sustainability are also a matter for business, but not only that. Asked about what they would like to see from politicians, companies said that they want reliable framework conditions and individual freedom, but they also want support. These include, in particular, tax incentives for sustainable products and services, information and support services, greater recognition of committed companies, consistent alignment of research and technology funding and public procurement with the principle of sustainability. (Look at Fig. 8.1.)

From this, the CCI derives the following recommendations for action for the economy:

- Develop and evaluate key figures: Companies should systematically and continuously develop and collect sustainability indicators. This gives them the opportunity to review and realign their own economic actions. This ensures the ongoing sustainability of the company.

- Develop innovation potential: Aligning the corporate strategy with sustainability criteria offers numerous impulses for change and innovation. This also contributes to future viability.

- Think digitisation and sustainability in tandem: Companies that use digital change for greater sustainability create value for society.

- Doing business responsibly together with others: Exchanging ideas with other companies or joining forces in sustainability alliances makes the path to greater sustainability shorter and faster. 


\section{The recommendations for action for politicians are as follows:}

- Create reliable framework conditions: Companies need reliable framework conditions for responsible business. Reliability implies long-term and coherent action at the national level on the basis of the same rules for everyone, beyond individual legislative periods and policy departments. At the international level, a level playing field is a prerequisite for success in international business. The federal government should therefore continue to advocate equal rules for all in multilateral forums and international organisations.

- Setting new incentives: Fiscal policy instruments such as tax incentives for sustainable products and services or a climate-friendly tax and contribution system would, in the opinion of business, promote responsible economic activity. Greater recognition of "best practice examples" can also provide additional support for corporate commitment.

- Strengthening dialogue and cooperation with supplier countries: Responsible business must look beyond Germany's borders. It is also about raising environmental and social standards in supplier countries on a lasting basis. It is the task of politicians to continuously promote dialogue and cooperation between German companies and governments, social partners and civic society organisations in supplier countries, and to further improve the legal situationalso with the help of German Development Cooperation. Support for companies with information on country-specific risks can be provided, for example, by the German embassies in cooperation with the Chambers of Commerce Abroad (AHK).

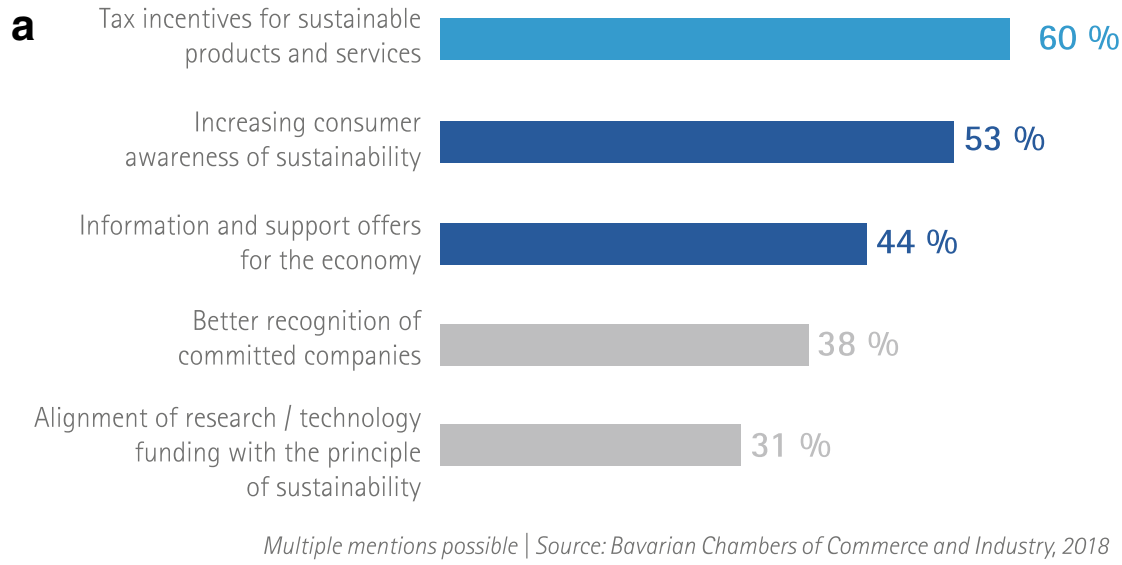

Fig. 8.1 Which framework conditions sustainability needs: What Bavarian companies expect from politics 
b Developing products and services that promote (individual) sustainability goals

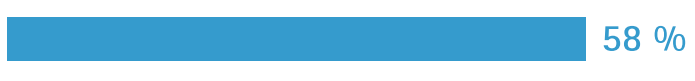

Integration of (individual) sustainability goals in the corporate strategy

\section{Public commitment to (individual) sustainability goals}

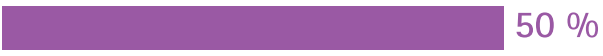

Donation activities

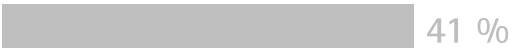

Projects / Partnerships with other actors

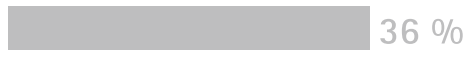

Source: CCl for Munich and Upper Bavaria, 2018

Fig. 8.2 How Bavarian companies are already integrating the Sustainable Development Goals into their operations

- Establishing sustainability as a guiding principle: Responsible economic activity also requires strengthening consumer awareness for more sustainability. This is where the National Action Plan for Education for Sustainable Development and the National Programme for Sustainable Consumption help. Consistent implementation of the measures formulated therein and accompanying information campaigns should further strengthen the willingness of consumers to demand sustainable products and services as such and to pay an appropriate price for them.

\section{And this is how the CCI supports the companies:}

- CCI Committee Corporate Responsibility: With the CCI Committee Corporate Responsibility, the CCI has created a body that works for better framework conditions, promotes best practice and networking.

- Educational work: As part of the National Action Plan for Education for Sustainable Development, for example, the Bavarian Chambers of Commerce and Industry are helping to anchor the issue of sustainability in the education chain. To this end, they support corresponding projects in initial and continuing vocational education and training, including the Energy Scouts - trainees who go in search of sources of energy waste in their companies and develop energy-saving solutions.

- Mega topic-environmental protection: For many years, the CCI has been providing information on all topics relating to energy saving and resource conservation, environmental management and biodiversity. It networks the players in internal and external working groups and supports the Bavarian Environmental Pact and the Bavarian Environmental Cluster. 


\section{Study on Sustainable Development Goals (SDGs)_Voluntarily Taking on Responsibility}

In 2015, the United Nations published the Agenda 2030 and condensed its demands for a more sustainable world into 17 goals, the so-called Sustainable Development Goals (SDGs). These have been in force since 1 January 2016. These goals are not legally binding for business. However, since UN requirements may in the medium to long term become not only national action plans with the character of recommendations but also national laws and ordinances that entail sanctions in the event of non-compliance, companies cannot circumvent the SDGs. At the same time, the integration of SDGs into the corporate strategy can bring them new customers, new markets or innovations. The Chamber of Commerce and Industry has therefore asked what companies think of SDGs, what benefits they bring to their business and, above all, what they need to implement them. (Look at Fig. 8.2.)

\section{The key results at a glance:}

- Fundamental significance of SDGs: Many companies are aware of the impact of their business activities on the environment and society. The overwhelming majority of the companies surveyed that are aware of SDGs, therefore, attach high or very high importance to them for their business.

- Strategic impulses: The companies generally view the SDGs in a positive light: The SDGs bring the issue of sustainability more strongly into focus within their companies, make it easier to align corporate strategy with the needs of the environment and society, point out new fields of innovation and help open up new markets.

- Key challenges: However, what companies lack to implement them is know-how and financial resources. At the same time, they stress the importance of partnerships for achieving SDGs.

On the one hand, the CCI derived recommendations for action for the economy from this:

- Taking responsibility: Companies should consider the effects of their own actions on future generations and across national borders and anchor corporate responsibility more firmly in their core business.

- Understanding SDGs as an opportunity: Indifferent companies should understand the SDGs as an impulse to review and, if necessary, realign their previous actions. 
- Moving forward together: It is particularly worthwhile for small and medium-sized companies to examine the possibilities of partnerships, industry and certification initiatives for higher sustainability standards along their value chains.

At the same time, however, the CCI addresses policymakers with recommendations for action, thus fulfilling its mission of representing the overall interests of the industry:

- Understanding the economy as a partner for the achievement of objectives: The state should see business as a partner in the achievement of objectives and actively involve it in the development and design of its sustainability strategy.

- Creating public awareness and stimulating a change in values: Politics should also anchor the necessary understanding of sustainability in the population along the entire education chain. Not only companies but also consumers must get on board.

- Expanding information and funding opportunities: Given that one of the biggest obstacles in companies' efforts to integrate SDGs into their corporate strategy is the lack of resources in terms of finance, expertise and technology, policymakers should introduce innovative incentive systems to further promote research and development in the field of sustainable products and services and also invest in forward-looking technologies. Support for industry initiatives and multi-stakeholder partnerships should also be further expanded.

And this is how the Munich Chamber of Commerce and Industry and the umbrella organisation Bavarian Association of Chambers of Commerce and Industry) support companies:

- Bavarian CSR Day: At the 5th Bavarian CSR Day 2017, the Bavarian Chambers of Commerce and Industry addressed SDGs and demonstrated in workshops how they can be integrated into a corporate strategy in an exemplary manner.

- Discussion forums: They initiated a discussion process with entrepreneurs in Nuremberg and Munich to elicit which practical levers sustainability needed to have an effect in business and society ranging from laws to digital solutions.

- Development of guidelines: Together with cooperation partners, the CCIs have developed guidelines on responsible supply chain management or stakeholder management, among other things. 


\section{Box: The 17 UN Sustainable Development Goals at a Glance}

1. End poverty in all its forms and everywhere

2. End hunger, achieve food security and better nutrition and promote sustainable agriculture

3. Ensure a healthy life for all people of all ages and promote their well-being

4. Ensure inclusive, equal opportunities, quality education and lifelong learning opportunities

5. Achieve gender equality and self-determination for all women and girls

6. Ensure the availability and sustainable management of water and sanitation for all

7. Ensure access to affordable, reliable, sustainable and modern energy for all

8. Promote sustainable, inclusive and long-term economic growth, full and productive employment and decent work for all

9. Build a resilient infrastructure, promote inclusive and sustainable industrialisation and support innovation

10. Reduce inequality within and between states

11. Make cities and settlements inclusive, safe, resilient and sustainable

12. Ensure sustainable consumption and production patterns

13. Take immediate action to combat climate change and its effects

14. Preserve and use the oceans, seas and marine resources in a sustainable development context

15. Protect, restore and promote the sustainable use of terrestrial ecosystems, manage forests sustainably, combat desertification, halt and reverse soil degradation and halt the loss of biodiversity

16. Promote peaceful and inclusive societies in the spirit of sustainable development, provide access to justice for all, and build effective, accountable and inclusive institutions at all levels

17. Strengthen the means of implementation and revitalise the global partnership for sustainable development. 


\section{Case Studies: UN Sustainability Goals-How Companies from Upper Bavaria Contribute to Their Implementation}

\section{First Tegernsee Coffee Roasting Plant-Fighting Poverty (SDG 1) Through Fair Prices}

Mario Felix Liebold, owner of the Erste Tegernseer Kaffeerösterei GmbH in Kreuth, not only wants to offer his customers the very best in coffee specialities he also sees himself as responsible for his suppliers, the operators of small coffee farms in Latin America, Africa and Asia. Therefore, he not only buys from them at fair prices without middlemen but also recommends them to other roasting companies. He also develops new coffee bean processing methods with them in order to expand their sales opportunities. In addition, he can also be relied on in difficult times, for example in the event of supply bottlenecks due to crop failures. Farmers can be sure that Liebold will then purchase smaller quantities and not cross them off his list of suppliers. "In this way we contribute to economic stability and growth. That's the best way to prevent poverty". Liebold emphasises: "Fair trade is our self-imageall the more so because our suppliers have often become our friends".

\section{Food Banks and Hipp Baby Food-Fighting Hunger (SDG 2) Through the "Tafeln" (Germany's Food Bank Charity) and Personal Commitment}

Hunger is not only an issue in developing countries and war zones. "Here in Germany, too, there are people who live in poverty and, therefore, take advantage of support services such as the "Tafel"; up to 16 percent of people here in Germany are considered poor or at risk of poverty", explains Jochen Brühl, Chairman of Tafel Deutschland. The "Tafel" currently supports around 1.5 million people at 2,000 distribution points throughout Germany with food that has been saved from waste. Their customers are very diverse: single parents, senior citizens, migrants, households with children. Brühl also expects help for these needy people from politicians and has called for federal and state poverty commissioners. At the same time, however, the "Tafeln" shows how companies can also help. "What is needed is the retail trade, which provides food that is still consumable but which has been deselected from sale" explains Steffen Horak, spokesman for Munich's "Tafel". The "Tafel" save 264,000 tons of food from destruction nationwide every year. "Companies can also help by donating money, by offering discounted or free services or by allowing their employees to donate time to us on Corporate Social Days, for example".

Among those companies committed to the food banks is the baby food manufacturer HiPP. Professor Claus Hipp has been patron and sponsor of Munich's "Tafel" since 1996. "It is our responsibility and task to help the poor among us" he sums up his motivation. "With Munich's "Tafel”, I am supporting an organisation 
that provides effective help, help that really gets through". However, Hipp sees his contribution to SDG 2 "Zero Hunger" in a much more fundamental way: "We can achieve this UN goal here and throughout the world more easily with sustainable agriculture - we at HiPP have been committed to this for over 60 years".

\section{Mondi Inncoat-Educational Progress (SDG 4) Through Further Training of Apprentices}

Profound training and continuous further education have always been a requirement at Mondi Inncoat $\mathrm{GmbH}$ in Raubling, a manufacturer of siliconised release papers. But education for sustainable development is also a major concern for the company. It is not just that all employees have learned to implement the eco-management system EMAS (the European Eco-Management and Audit Scheme). Since 2015, interested trainees have also been trained as energy scouts. They learn to recognise and plug energy holes. "Large energy losses are caused by compressed air leaks, for example, and our scouts have achieved savings of EUR 17,000 here", says Maintenance Manager Karlheinz Froschmayer proudly. "Above all, however, they infect the entire workforce with their enthusiasm for ecology".

\section{Gebrüder Peters-Promotion of Women (SDG 5) Through Equal Opportunities at Work}

Gender equality has long been high on the agenda of the Ingolstadt-based family business Gebrüder Peters GmbH. Authorised representative Veronika Peters naturally pays men and women the same for the same work. She makes sure that women move up into management positions and prepares them for this in mentoring programmes, among other things. At the same time, she supports a good balance between family and career. Home office, flexible working hours, part-time or job sharing are also possible for managers. Single parents receive additional financial support, which at present stands at EUR 1000 per year, which they are free to use as they wish. Peters emphasises: "We always offer the work life balance opportunities to both genders. Because only if men also take on more family work can new role models and truly sustainable gender equality also be established".

\section{ECOFARIO ${ }^{\circledR}$ C Clean Water (SDG 6) Through Innovative Microplastic Control}

The Munich start-up ECOFARIO® GmbH has declared war on microplastics in waste water. "Microplastics per se have no place in nature. Moreover, they combine with toxins and pollutants that are also in the waste water-this makes them even more dangerous", explains founder Sebastian Porkert. "Since the conventional filters in waste water treatment plants are not fine enough to filter out microplastics, 
it usually ends up back in surface waters with the pollutants after waste water treatment”. ECOFARIO ${ }^{\circledR}$ now separates the microplastic from the water by means of extreme vortex currents, the plastic can thus be enriched and burned together with the sewage sludge. "As long as we do not avoid microplastics, our approach can help to subsequently mitigate the dangers".

\section{Salus Haus Dr. Med. Otto Greither Nachf.- Clean Energy (SDG 7) Through Our Own Hydroelectric Power}

It was a small hydroelectric power station on the Mangfall river, which was built for Salus Haus Dr. med. Otto Greither Nachf. GmbH \& Co. KG in 1968 to settle in Bruckmühl in Upper Bavaria. "As a manufacturer of natural remedies, our economic success is particularly dependent on an intact environment", emphasises Salus Sustainability Manager Cassandra Heimgartner. "That's why we have always considered environmental protection and wanted to use nature-friendly energy sources right from the start. Hydropower fits perfectly into the concept". In 1990, Salus acquired a second hydroelectric power plant and has since installed numerous photovoltaic systems. In this way, up to 90 percent of the electricity consumption can be covered by the company's own regenerative power supply, the rest is purchased from green electricity. The green electricity supply at Salus is part of a comprehensive energy management system based on EMAS, the European Eco-Management and Audit Scheme. It is accompanied by numerous technical energy efficiency measures such as LED lighting or highly efficient pumps. A sophisticated waste heat recovery system enables Salus to save energy for heating, and cooling is provided by river water or fresh air wherever possible. "Hydroelectric power alone reduces our $\mathrm{CO} 2$ input by around 1000 tons per year", says Sustainability Manager Heimgartner proudly.

\section{Munich Airport-Innovation (SDG 9) and Climate Action (SDG 13)}

Developing and implementing a sustainable corporate strategy - Munich Airport is well aware of the challenges involved. The 17 Sustainable Development Goals (SDGs) published by the United Nations in 2015 proved to be a helpful toolbox for the company. "Munich Airport has been committed to sustainability since 2008", explains Christina Berghäuser from the Strategic Sustainability Management Team. "Sustainability is part of our corporate strategy, and we have developed many concepts and individual measures".

The airport used the SDGs as an opportunity and benchmark to reorganise, develop and deepen its existing activities. In a comprehensive discussion process with employees and partners, twelve SDGs were selected and translated into projects that are particularly relevant to the airport. Berghäuser emphasises: 
"The SDGs are a good strategic and practical orientation framework for the sustainable orientation and management of the company".

These two examples show how Munich Airport implements the SDGs in strategy and practice: By 2030, the airport aims to be climate-neutral, i.e. to advance SDG 13. To this end, the vehicle fleet and apron vehicles such as aircraft staircases and tow tractors are being converted to electromobility and energy-efficient construction is being further promoted. Or SDG 9: A new innovation centre is being built at the airport-the LabCampus. Here, companies, research institutions, start-ups and creative minds will jointly develop, test and present new products and services. And, last but not least, many of these innovations will contribute to sustainability - and not only for the airport itself. To ensure that it does not come to a standstill, the airport has set up a new SDG discussion round. All business units and partners are invited to participate in round tables "to become aware of what the company as a whole and each individual is already contributing to sustainability but also where it needs to be adjusted", explains Christina Berghäuser. "This is because, in addition to all the strategic approaches and practical measures, sustainability and SDGs need one thing above all else: a clear communication concept that makes them even better known both internally and externally. Then more ideas are generated-and more impact is created".

\section{CSR Guidelines-Helping Companies on Their Path Towards Responsible Business Practices}

With detailed and practice-oriented guidelines, the CCI enables companies to operate more responsibly. This is shown, for example, by the working materials from the Environmental Pact pilot project "Sustainable Supply Chain" and the multiplier guide on human rights diligence in companies.

Asking where companies stand and what they need to do to act responsibly is one side of the coin. The other is to empower companies to act accordingly. Only in this way can the honourable merchant move from a mission statement and a personal attitude to a management approach, to Corporate Social Responsibility. The CCI for Munich and Upper Bavaria as well as all Bavarian Chambers of Commerce and Industry contribute to empowering companies and strengthening this management approach with practice-oriented guidelines. The guidelines have been realised together with the Bavarian state government or special government initiatives. Two examples show how this empowerment works.

\section{Guide on Sustainable Supply Chains-Multiplying Practical Tips}

Both German and Bavarian industry are globally active. In 2017, Germany was the third strongest exporting country after China and the USA. However, being 
globally active means not only exporting but also purchasing or having products manufactured abroad. Accidents like the one in a factory in Bangladesh in 2013 prove, however, that not every supplier chooses to work under humane conditions. At the same time, there are already tried and tested ways of making the supply chain responsible and sustainable for both people and the environment. Together with the Bavarian State Office for the Environment, the Bavarian Chambers of Commerce and Industry have developed working materials within the framework of the Bavarian Environmental Pact, which primarily support small and medium-sized companies. The following key questions show where the path is leading. In the guide itself, they are answered with many practical tips, keywords are mentioned here.

- Recording and evaluating sustainability impacts: The company gains an overview of the entire value chain and evaluates and prioritises sustainability impacts along the individual production steps.

- Reviewing and adapting central business processes in the company: The company checks which existing measures and processes can already be used in its own company within the framework of sustainable supply chain management, or which need to be adapted or newly implemented. This step is important to create the internal foundations for sustainable supply chain management.

Possible courses of action here include, for example, appointing a person responsible, raising awareness among the teams, developing criteria and goals, and taking stock of the situation.

- Informing suppliers and defining requirements: The company communicates its requirements to suppliers. The requirements for suppliers are made binding. Here, for example, the development of codes of conduct or contracts as well as dialogue with suppliers and obtaining their signatures are helpful, as is a distancing from suppliers in the event of non-implementation.

- Reviewing the sustainability performance of suppliers: The company checks whether the requirements are implemented by suppliers. It can use various approaches to do this.

The company can also call on external experts from NGOs or industry initiatives.

- Training suppliers: Building on this, the company conducts training and other measures with suppliers, where necessary, to raise their awareness of sustainability issues and thus improve their sustainability performance.

Here, the company can develop its own training courses or commission external service providers.

- Disclosing information: To facilitate internal and external stakeholder exchange and promote transparency, the company reports on its sustainable supply chain management.

Those who have improved their supply chain should evaluate and improve it again and again, but at the same time communicate their progress to stakeholders. 


\section{Multiplier Guide on Human Rights Diligence - Getting Small and Medium-Sized Companies on Board}

In the case of companies with more than 500 employees, its implementation will be reviewed. If, in 2020, at least 50 percent of companies based in Germany with more than 500 employees have not implemented the core elements described in the National Action Plan, the German government reserves the right to take further steps - all the way up to legal action. In cooperation with the Global Compact Network Germany and the human rights management consultancy twentyfifty, the Bavarian Chambers of Commerce and Industry have developed the guideline "Human rights diligence-relevance and options for action for small and medium-sized enterprises (SMEs)" in order to support companies. The target group here is primarily the multipliers - i.e. NGOs, the chambers themselves or consulting firms. They need to be empowered to sensitise SMEs regarding human rights and to advise them on suitable measures. At the same time, the companies themselves can use this guide. The following 17 questions provide an insight into how the guide works.

1. How do I know whether human rights are relevant to my company?

2. How can I, as an SME, get started on the issue of human rights?

3. What does "human rights due diligence" mean?

4. How can I implement human rights due diligence in my company?

5. What do I need to consider if I want to invest in country $x$ or contract suppliers there? Where can I find information on the human rights situation? Is it enough to look at local legislation?

6. I can't do everything at once, can I? How can I set the right priorities?

7. How can I communicate the issue of human rights in my company?

8. I already have a CSR or sustainability programme in my company. How is this related to human rights?

9. What do human rights have to do with responsible supply chain management?

10. One of my customers asks whether we as a company provide fair and safe working conditions in accordance with the ILO core labour standards. How should I answer?

11. I adhere to the provisions of German labour law and ask my suppliers to comply with the ILO core labour standards - Surely that means my part is done, doesn't it?

12. How far does my responsibility in the supply chain reach?

13. How can I cooperate with others?

14. What do I do if one of my suppliers is found to be guilty of serious human rights infractions, such as forced or child labour?

15. I have been doing social compliance audits in my supply chain for a long time. Is there anything else I need to do?

16. The topic of anti-corruption is becoming increasingly important for companies that operate internationally. Are there any connections with human rights here?

17. How can I communicate the topic in my reporting? 
The following answer to question 3 shows as an example what the guide provides:

What does "human rights due diligence" mean? Human rights due diligence is the process by which you ensure and demonstrate that your company respects human rights. It helps to anchor respect for human rights in the company. Human rights due diligence first means systematically identifying where people are (or could be) harmed by the company's actions. Then it is a matter of taking appropriate measures to prevent or repair this damage. This process is different for every company. The type and scope of measures a company needs to take depends on its own risk profile, i.e. the risk of adverse human rights impacts through its business activities or relationships.

\section{Case Studies: Supply Chain and Human Rights-How Companies Set Priorities}

\section{Kokadi-Fair Conditions for Farmers}

The Kirchheim-based company Kokadi GmbH \& Co. KG, which manufactures and distributes baby slings, has had human rights in mind since its foundation. "We are convinced that the only right way for a better future is a clean, fair and ecologically sound production. Every entrepreneur has the power to do so in their own hands and, of course, I use the resources provided with pleasure and with full conviction", explains Kokadi founder and Managing Director Ceyda Temur. She has the fabrics produced in Turkey, and the cloths are manufactured in Slovakia as the end product. The cotton is certified according to GOTS, the demanding Global Organic Textile Standard. Temur only works with farmers who grow the cotton in a sustainable way and checks that their partners in the production guarantee fair working conditions, good wages and further training for the weavers, dyers and seamstresses. Ceyda Temur: "This is what our customers expect, fairness and human rights are also a sales argument for us".

\section{Greiff Mode-Human Rights Due Diligence Has the Highest Priority}

Long before the National Action Plan on Business and Human Rights (NAP) was even mentioned, GREIFF Mode GmbH \& Co. KG in Bamberg put the subject of human rights on the agenda: In 2010, the management of the company, which has been in existence since 1802 and specialises in workwear, started an intensive discussion surrounding values with its approximately 100 employees. "Human rights due diligence was the top priority, along with sustainability: We didn't want to turn a blind eye to the issue", says Nicole Wagner, CSR officer, whose position was created specifically to implement the results of the discussion in 2014. GREIFF 
first took a look at the supply chain. The company works with around 20 contractors, including some in countries where human rights are controversial. "We have been in ever closer contact with the partners in these countries, we have been on site, talked to them about fair working conditions, had them sign a code of conduct", explains Wagner. "However, we did not have the means to check whether they were actually complying with the code". To change this, GREIFF joined the internationally active non-profit organisation Fair Wear Foundation, which aims to improve working conditions in the textile industry on the basis of the Universal Declaration of Human Rights. The Fair Wear Foundation goes to the subcontracting companies working for GREIFF, talks to both management and employees, works out measures together with the companies and with GREIFF and checks their implementation. These steps are regularly repeated in the sense of continuous improvement. At GREIFF the second round is currently just beginning. The results are convincing for Nicole Wagner: The audited suppliers have meanwhile demonstrably increased work safety, GREIFF knows that minimum wages are definitely paid, overtime is announced and remunerated, and breastfeeding mothers are better protected. Together with the Fair Wear Foundation, GREIFF is setting up a complaints mechanism in the partner companies. Employees can contact and report grievances anonymously and without fear of being discovered. "Nobody at our suppliers has used this so far, but it is an important offer", says Wagner. In the form of a social report, GREFF reports annually on its homepage about the improvements in the subcontracting companies. In addition, interested parties can follow the textile supply chain of the products online via a code sewn into the textiles, the My-GREIFF code. However, GREIFF's human rights commitment does not end with Fair Wear. On the initiative of its employees, the company has launched a new Fair Trade collection. And last but not least, it joined the German "Alliance for Sustainable Textiles". All of this is bringing GREIFF ever more economic benefits. "It makes us attractive to our employees, they are proud of their company", says Wagner happily. "And more and more customers and clients are also signalling to us that our sustainability work was the basis for their purchase decision or awarding of contract". She re-emphasises: "Human rights are a deep and honest concern for us. But, of course, we are also happy if we can generate economic benefits with them".

\section{CSR Within the $\mathrm{CCl}-$ More Responsibility Together}

Encouraging and empowering companies to be more sustainable and responsible is one side of the coin. The Munich Chamber of Commerce and Industry has set up a strategic process that culminates in a roadmap known as the "Economy and business for the future" and a sustainability report-and this is far from over.

To carry the model of the honourable merchant to the outside world is only credible if it is also embraced internally. The CCI brand identity "Together we take responsibility", with which the German Chambers of Commerce and Industry have 
further developed the "CCI" brand, also on the initiative of the Bavarian Chambers of Commerce and Industry, is therefore also the internal guideline for the daily actions of CCI employees. The CCI for Munich and Upper Bavaria, Germany's largest chamber of commerce and industry, has set up a strategic process in this sense, which has resulted in a roadmap entitled "Economy and business for the future" and a sustainability report for the CCI Munich itself. The sustainability report and a corresponding future magazine make it clear how the Munich Chamber of Commerce and Industry contributes to the future viability of companies, supports sustainable development but also continues to develop as an organisation. Details of internal sustainability work:

Sustainability report: What are we already doing? Where do we want to go? The CCI decided to answer these questions systematically in a sustainability report. It chose the German Sustainability Code (DNK = Deutscher Nachhaltigkeitskodex) as the framework for the report. Today, almost 500 German companies report according to this framework. The DNK demands statements on 20 principles of responsible corporate management in the four areas of strategy, process management, environment and society.

- Strategy: First of all, the CCI will analyse and further develop its existing strategies and measures, and in doing so will primarily translate the concept of the honourable merchant into the work of the organisation.

- Process management: Subsequently, key figures, rules and processes, control and incentive systems will be analysed, redefined if necessary and responsibilities will then be determined. After all, sustainability must be measurable.

- Environment: In particular, the CCI will present its handling of natural resources and climate-relevant emissions and set concrete goals: How much $\mathrm{CO} 2$ is emitted? How much paper and electricity are consumed? What are the future goals?

- Society: Last but not least, employee concerns, equal opportunities, qualification, human rights and the role of the CCI for the community are put on the agenda.

Steering committee: In order to be able to implement the agreed goals accordingly, a steering committee will be set up as an internal management body, in which employees from all areas are represented.

Employee involvement: To ensure that the brand identity is firmly anchored in the workforce, the divisional, departmental and unit heads are trained in workshops so that they can then pass on their new knowledge to employees as multipliers. All employees should be inspired by the brand identity.

Although systematic sustainability management is still in its infancy, a number of individual measures have already been taken to ensure sustainable corporate management: 
- Energy efficiency: The headquarter's building has been renovated to be energy-efficient and uses district heating and cooling.

- E-mobility: Bicycles and electric cars are available in the CCI mobility pool.

- Train before plane: When travelling on business, employees are called upon to take the train whenever possible and not to fly-or to make use of telephone or Skype conferences.

- Reusable: In the canteen, disposable cups were abolished in favour of reusable cups. Floor coffee machines that work with disposable coffee capsules have been replaced by more environmentally friendly alternatives.

- Paperless office: The departments are encouraged to work with as little paper as possible. Invitations to events will also no longer be sent by post.

- Sustainable events: At events, less and less printed information will be made available and more and more digital formats will be on offer.

- Family friendliness and more: In the area of employee issues, the CCI places great emphasis on the compatibility of family and career and on having more women in management positions. Preparations are also being made for workplace health promotion.

\section{Out-of-Court Dispute Resolution-Charting a Shorter Route to a Win-Win Situation}

If you want to embody the honourable merchant, you first try to find an out-of-court solution in case of dispute. The Chamber of Commerce and Industry for Munich and Upper Bavaria enables companies to do this by providing mediation, arbitration and arbitration expertise.

It is impossible to prevent disputes within and between companies. However, the contracting parties can avoid a situation where the dispute drags on, or where it becomes expensive and they no longer acknowledge each other after the dispute. Out-of-court dispute resolution procedures create the possibilities for this: The Chamber of Commerce and Industry for Munich and Upper Bavaria offers two formats in the form of business mediation and arbitration in addition to the out-of-court offers entrusted by the state: the expert system and the conciliation board for competition disputes (see chapter "Public tasks assigned by the state").

With good reason: State courts, the CCI argues, should always be the final resort. This is because the self-image of a self-organising economy and the model of the honourable merchant not only envisages that the word and the handshake of business people are sufficient for making binding agreements. It also means that, in the event of a dispute, independent, joint solutions are first sought, independent of state authority. The business community regulates its own affairs before taking legal action, according to the conviction of both primary and honorary employees. 


\section{Arbitration Court and Mediation Centre}

Thus, the general assembly of the Munich Chamber of Commerce and Industry also agreed when the primary office proposed that the Chamber of Commerce and Industry establish out-of-court offers more than 20 years ago. The primary office then gradually developed and expanded the offers. The Munich Chamber of Commerce and Industry has had its own arbitration court since 1997. 1998 saw the opening of the first mediation office, and in 2006 the now renowned Mediation Centre was finally established.

\section{Advantages of Extra-Judicial Dispute Resolution}

Experience shows that businesses are making use of the out-of-court solutions more and more. This is also because they are generally not only faster, cheaper and more discreet but also usually more sustainable: Facilitated by specialised dispute mediators who are well-versed in the respective economic field and who also have a certain talent for understanding the psychological dimension behind such developments, out-of-court procedures can lead to consensus and win-win situations which allow the parties to the dispute to talk and work together again thereafter. Another argument in favour of attempting to achieve an out-of-court settlement is that state courts are often overburdened or that many judges, despite all their legal skills, lack a specific economic background and thus a certain basis for economic assessment.

\section{Prevention Through Contractual Clauses}

Nobody can be forced to settle a dispute out of court-not like a state court to which one can be summoned. Thus, the out-of-court settlement of disputes always begins in advance, when the dispute is not yet foreseeable. In a best case scenario, the contracting parties make a precautionary decision during the contract negotiations on clauses that they will try to reach an out-of-court settlement in the event of a dispute - initially by means of mediation. If this does not succeed, the arbitration court, for example, is the next option. For this purpose, the Munich Chamber of Commerce and Industry has drafted legally sound clauses which companies can incorporate into their contracts and which are also available in English: 
Box: Mediation and arbitration clause of the $\mathrm{CCl}$ for Munich and Upper Bavaria

- Mediation Clause: In the event of a dispute arising from (or relating to) this contract, the parties undertake to conduct mediation in accordance with the provisions of the CCI Mediation Centre of the Chamber of Commerce and Industry for Munich and Upper Bavaria prior to bringing any legal action before an ordinary court (or arbitration tribunal).

- Arbitration clause: All disputes arising in connection with the contract (exact description of the contract) or concerning its validity shall be finally settled in accordance with the Rules of Arbitration of the Chamber of Commerce and Industry for Munich and Upper Bavaria (CCI Munich) under exclusion of the ordinary course of law.

\section{Procedural Advice by the $\mathrm{CCI}$}

Essentially, it stipulates that every conflict has a suitable out-of-court procedure, but not every out-of-court procedure is suitable for every conflict. Therefore, the Munich CCI experts see procedural consulting as their first task. Which procedure fits the conflict brought before the CCI either by one or both parties to the dispute? These are the three steps:

- Explaining the procedures: The CCI explains the various procedures, analyses the conflict with the parties in dispute and provides neutral advice on which procedures are suitable-from mediation to arbitration.

- First procedural steps: It advises on how to find suitable mediators or suggests suitable persons itself. The parties then choose their own mediator. If they cannot agree on one person, the CCI can choose the mediator.

- Implementation: The parties carry out their procedures independently of the CCI or use (administered) procedures developed and supported by the CCI.

\section{Arbitration Court-Utilising National and International Advantages}

Arbitration courts are well known in business circles. They stand for a traditional form of out-of-court dispute resolution that has proven itself particularly well in international disputes. In Germany, the first arbitration proceedings date back to the 17th century. In connection with the suspended TTIP trade agreement between the 
United States and the European Union, arbitration proceedings in Europe have become increasingly popular with the general public.

\section{The advantages of arbitration}

In case of an unsuccessful mediation, the Chamber of Commerce and Industry sees an arbitration court as the next chance for an out of court settlement. The companies generate and confirm these advantages.

- Discretion: An arbitration process is not public, thus very discreet, and the reputation of the opposing parties is preserved.

- High economic expertise among the arbitrators: The parties and their lawyers present their arguments to up to three arbitrators, who are always specialised in the field of conflict in question and do not have to familiarise themselves specifically. This expertise of these arbitrators is considered a particular advantage.

- Conclusion: The arbitrators make an arbitration decision, which as a rule cannot be appealed against - neither at the arbitration proceedings nor at a state court.

- Time saving: Since there is only one authority, an arbitration process is usually faster. This ensures that all parties involved are well prepared and start the proceedings with a high degree of willingness to reach an agreement-thus arbitration proceedings often end in a settlement that is acceptable to all parties.

- International recognition of arbitral awards: In cross-border disputes, an additional advantage is that arbitral awards are also enforceable abroad under a 1958 United Nations Convention. State judgements, on the other hand, are often much more difficult to enforce in non-European countries.

- Support from the Chambers of Commerce Abroad: In disputes with foreign companies, the Chambers of Commerce Abroad (AHK) also support the parties to the dispute; they usually act as arbitration institutions.

\section{Administers Arbitration Proceedings}

The Chamber of Commerce and Industry for Munich and Upper Bavaria has had a court of arbitration since 1997. It is thus one of the three most important arbitration locations in Germany. The CCI Munich is a member of the German Institution of Arbitration (DIS) and administers arbitration proceedings according to its own arbitration rules. It also appoints arbitrators.

\section{New (SME-Friendly) Arbitration Rules of the CCI}

Since 15 May 2018, the new arbitration rules of the Chamber of Commerce and Industry for Munich and Upper Bavaria have been in force. These rules provide for a single judge and only a six-month period for proceedings. Those who agree to 
these rules will receive a 20 percent discount on the procedural fee. This reform will make arbitration proceedings shorter and more cost-effective and also more interesting for smaller companies.

\section{Infrastructure for Arbitration Courts at the CCI}

The CCI also provides the infrastructure for the arbitration court: in urgent cases, an arbitration claim can be submitted to the CCI via a night mailbox or in electronic format. The CCI has built up a pool of competent arbitrators, from which it proposes an arbitrator to the parties in dispute. If the parties cannot agree on someone, the CCI president will appoint the arbitrator. The procedure itself takes place on the premises of the CCI.

Box: Arbitration procedure "light"-Arbitrator's Report Instead of Arbitration As an alternative to arbitration, the parties may also agree on an arbitrator's report. The aim of the arbitrator's expert opinion is to have disagreements between the parties to the contract with regard to the content, interpretation or adaptation thereof bindingly resolved by an independent, impartial and professionally competent expert, i.e. the arbitrator. In principle, the subject matter can be anything that can be assessed by experts: from defects in the construction of a house to the value of an object of art. In contrast to an arbitration judgement, an objection to an arbitrator's expert opinion can be lodged with a state court. (See also article on "Experts" in Chap. 4)

\section{Mediation-Striving for Consensus}

Court proceedings, as well as out-of-court arbitration proceedings or arbitration opinions (see above) are characterised by the fact that a third party, once all arguments have been presented, passes judgement on behalf of the parties in dispute. Mediation takes a different approach. Moderated by an impartial third party, the mediator, the parties in dispute negotiate with each other in mediation until they have found a compromise acceptable to both sides. The mediator is not a judge, he does not pass judgement, he merely mediates the respective positions. The disputants find the compromise themselves.

In principle, mediation is not a new form of dispute resolution. It was already known in the societies of European antiquity. In the Middle Ages, the Peace of Westphalia, which ended the Europe-wide 30-year war in 1648, was considered a successful result of mediation. One of the greatest successes of mediation in modern times is the peace agreement between Israel and Egypt, which was negotiated in Camp David. Nor is mediation a specifically Western phenomenon. It is a common 
means of dispute resolution worldwide - although not always under the name of mediation.

Gradually, however, the business community has also recognised its benefits. The Chamber of Commerce and Industry for Munich and Upper Bavaria already made progress here in the 1990s and was one of the first chambers of commerce and industry to establish its own structures for business mediation.

\section{Legal Quality Assurance-The Mediation Act (MediationsG)}

Finally, since 2012 there has been a Mediation Act in Germany. It legally accompanies the dispute resolution process in a mediating capacity. On the one hand, the law regulates mediation in state courts and provides for state judges to act as so-called judges of property. The law also regulates the admission and quality of non-judicial mediators. The Chamber of Commerce and Industry for Munich and Upper Bavaria was a member of the committee of experts that prepared the law and contributed to the content of the law. It was primarily concerned with the quality assurance of mediation and the certification of mediators.

\section{Proprietary Mediation Centre in Munich with Its Own Rules of Procedure}

The Chamber of Commerce and Industry for Munich and Upper Bavaria sees particular advantages for the economy in a mediation procedure, which is why it places particular emphasis on this area. It has been offering mediation since 1998 and has had its own Mediation Centre since 2006. This centre has rules of procedure and a pool of 140 certified mediators from which the parties in dispute can choose a suitable personality — or have one recommended. Every year, around 300 companies in the Munich and Upper Bavaria chamber district use mediation.

\section{Growing Areas of Application for Mediation}

At the same time, the areas of application are expanding with ever greater reach: While mediation was initially often used for conflicts between companies or between managers within a company, more and more conflicts are now being solved through mediation in teams or between teams and supervisors.

\section{The Practical Role of the $\mathrm{CCl}$ in Mediation}

The Chamber of Commerce and Industry for Munich and Upper Bavaria supports companies in mediation proceedings both in the run-up to and along the way. 
- Consulting and sample clauses: The CCI advises on mediation and provides model clauses for contracts.

- Appointment of mediators: It appoints competent and neutral business mediators. Over 140 mediators are listed in its pool.

- Quality assurance: The CCI only accepts mediators into its pool that are characterised by a high degree of integrity and honesty, and who also have relevant business experience in specific areas. The Mediation Centre ("MediationsZentrum") verifies their suitability and requests proof.

- Rules of procedure and, if requested, administration of the procedure: The CCI offers rules of procedure on the basis of which it administers the mediation procedure for the parties in dispute: it sets up the rules of procedure, provides suitable rooms for meetings and, upon request, also issues enforceable titles on settlements that have been reached. However, the parties in dispute and the mediator can also work together independently of the Chamber of Commerce and Industry according to their own wishes.

- Bavarian Mediation Day: With the regular Bavarian Mediation Day, the CCI promotes the topic of mediation and brings together interested companies, mediators and the judiciary.

- Training of mediators: By qualifying as a Business Mediator (CCI), the Chamber of Commerce and Industry has developed a training procedure at its own CCI Academy, which has met with a very good response in Southern Germany.

- Court-based mediation: It has introduced a further proposal with court-based mediation. In this case, faltering business processes before state courts can be interrupted and an external Business Mediator then attempts to solve the case by way of mediation.

\section{Advantages of Mediation}

Companies usually have good experiences with mediation. They mainlymention the advantages listed below. The compromise reached is binding when an enforceable copy from the Chamber of Commerce and Industry or a notarial certificate is issued. The advantages in summary:

- Sufficient time: In mediation, the parties in dispute and the mediator take the time they need, and yet it is usually faster than a court process that may go through several authorities.

- Intensively processing the conflict: On the one hand, the contracting parties negotiate the topic more specifically with each other because the accompanying mediator usually has a good understanding of the area of dispute and the industry and can moderate accordingly - the Chamber of Commerce and Industry also pays attention to this when proposing the mediator. On the other hand, mediation usually approaches the conflict in a more fundamental way, it 
questions the dispute, looks behind the external cause. Thus, even with experienced businessmen/women, emotional outbursts can sometimes occur because an emotionally charged conflict is concealed behind the superficial subject matter, which the mediator brings to the surface with a great deal of sensitivity.

- Discretion: Since mediation never takes place in public, the parties involved can afford to express these feelings without shame.

- Win-win situation: In the best case, the dispute is completely resolved after mediation and trust is restored, so that the parties can even continue working together afterwards.

- Favourable costs: Another advantage of mediation is the lower costs. A mediation procedure is not measured by the amount in dispute. The costs arise mainly from the hours spent by the mediator.

- Singapore Convention: The Singapore Convention, which was adopted in 2019 and is based on a template from the United Nations, will make it possible to enforce agreements drafted under mediation in international trade disputes worldwide. Now the nation states must implement the Convention.

\section{Case Studies: Mediation-How Companies Can Sustainably Resolve Disputes}

Using two anonymous examples, we will show how effective mediation can be for companies in dispute - and how it can even help bring the companies back together.

\section{Construction Industry: Ending Disputes in Court}

For a full 2 years, says the Munich-based Dr.Kainz \& Partner law firm for private construction law, architectural law and public procurement law, two companies-a construction firm and its client-fought mercilessly in various courts. Initially directly, and subsequently through their subsidiaries that were actually completely uninvolved. Previously, the two companies had enjoyed good and even mutual business relations for decades. The "known" reason for the radical change: alleged construction defects and, as a consequence, in the payment of invoices. Several judgements were passed, and a lot of time, money and nerves had already been invested. Despite this, the opponents, who had long since ceased to act rationally, were always looking for (and were able to find) a way to drag their opponent before the judge. A mediation procedure led by the Kainz law firm, to which they were fortunately persuaded, quickly revealed the deeper cause of this doggedness. In 
one-on-one meetings, which were scheduled without their respective trial representatives, they explained bluntly why, in their view, they could not give in at all. Their legal colleagues showed understanding for this request-the one-on-one meetings - especially since they themselves had long been irritated by the extraordinarily rocky road the dispute had taken so far. Subsequently, the Kainz law firm learned that the owner of the construction company, who is also a functionary in various industry associations, was far less hurt by the loss of profit than by the damage to his image that he feared to suffer as a result of the - only partialrecognition of construction defects. The firm found a similar motive with the client. There, the junior boss had taken over control at the very moment the new building was handed over. He was, therefore, in the process of shaping his own style both internally and externally. This also had an impact on his conduct in connection with the disputed building defects. Any subsequent yielding on his part, therefore, seemed to him to be an unacceptable signal of weak leadership. For the firm, the solution to the problem was thus obvious. All that was needed was a discreet but clearly formulated indication to both of them that their litigation frenzy was increasingly provoking the very damage to the firm's image with outsiders that they actually wanted to avoid. In the end, the mediator is pleased with the resulting success, as both companies are even doing business with each other again.

\section{Advertising Industry: Overcoming Differences of Opinion}

At first there was a good vibe. "We got along well personally", says the founder and Managing Director of a Munich photo agency and photo community about his former co-partner, the owner of a Munich advertising agency. When the two got to know each other, they quickly agreed that a form of business cooperation could be useful for both of them. At the end of 2005, the advertising agency boss joined the picture agency as a partner. The young, rapidly expanding company was to benefit from his know-how in the field of public relations and marketing, and in return he was to gradually receive more shares in the company. But after a few months there were differences. "There were different opinions about the corporate strategy" says the advertising agency boss. After many discussions and warnings, one thing became clear after a year: further cooperation would no longer be possible. Both parties consulted their lawyers, who agreed that the contracts were highly complicated. A legal dispute can therefore be quite lengthy, the outcome completely open. The opposing parties decided on an alternative and agreed to try mediation. The head of the picture agency therefore turned to the mediation centre of the CCI. They were looking for a neutral third party, a mediator who is specialised in company, media and labour law and who knows the industry. The CCI recommended Prof. Dr. Mathias Schwarz, a lawyer and mediator experienced in the field of media and internet, who is also a certified public accountant. "Prof. Dr. Schwarz fulfilled all our expectations", says the boss of the picture agency. The first mediation meeting was held at extremely short notice, after just two days. In a relaxed atmosphere, the opponents meet in the office on neutral ground for a long, 
intensive conversation. Both parties greatly appreciated the neutrality and expertise of the mediator. "During the conversation, the hardened positions loosened up", says the advertising agency boss. "Everyone reflected on their situation and tried to understand the other's point of view". It is necessary to find a sensible solution in terms of corporate law and tax law. While the proposed solutions were still far apart at the beginning, both sides also showed very clearly that they were looking for an agreement, says mediator Schwarz. At the end of a strenuous but productive day, the three of were convinced that they would find a joint solution. The second session therefore lasted only a short time-within two hours the key points of the agreement were jointly put down on paper. After one week, the mediation was concluded and the conflict was resolved amicably. One year later, the two parties are still very satisfied with their agreement. Compared to a dispute in court, both of them consider speed and low costs to be the most important arguments for mediation. And with a view to the future, the head of the picture agency says: "We can look each other in the eye again, even some form of cooperation would be possible for me again on another level".

\section{Portraits}

A CCI lives from its members. The more committed they are, the better the tasks of the CCI can be implemented - especially the overall representation of interests but also a number of public tasks assigned by the state. The following portraits demonstrate this.

The CCI for Munich and Upper Bavaria was spoilt for choice. Quite a few members work intensively for the Chamber on a voluntary basis, as examiners, in the technical committees, in the regional committees and in the general assembly. The portraits below are therefore only a small selection of committed CCI members who are above all committed to the model of the honourable merchant. They want to advance their companies but also the economy as a whole - but not at any price. They take responsibility for employees, partners, the environment and society and always look beyond their own horizons. 


\title{
Portrait 1: Klaus Bauer, Bauer Unternehmensgruppe GmbH \& Co. KG-Defining Shared Knowledge as Practical Benefit
}

\author{
Klaus Bauer, Photo Credit: CCI for Munich and Upper Bavaria/Goran \\ Gajanin_Das Kraftbild
}

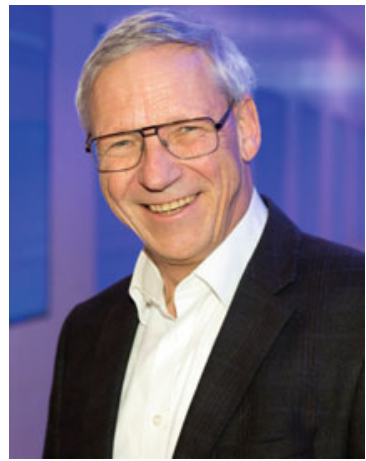

It has been a while since Klaus Bauer became the "successor" of the family business. Quite the opposite, as his daughter Barbara, has just succeeded him in the fourth generation in the management of the family business in Weilheim, Upper Bavaria. But the thoughts that moved him, the perspectives he faced and the responsibility he assumed when he himself joined the management in 1979 are still present in his mind. At that time, for example, he could not imagine how the economic area of Upper Bavaria would develop in four decades - and what that would mean for his own company. "At that time, I set myself the goals of further developing the location that previous generations had built up and making the company fit for the future. As a young person, I perceived Upper Bavaria as a limitation, not as an opportunity. It has developed in a completely different way".

In his view, this development is particularly visible in two places. On the one hand, there are the high-tech landscapes in the north of Munich around Garching with its technological centres. On the other hand, he also notices serious changes where the Bauer Group is at home, in the area around Landsberg am Lech and Weilheim. "This region has expanded through good work and sound economic policy, and through agile entrepreneurs, of course. We all benefit from this - and must now accept the consequences". For example, the fact that only limited space is available to expand existing companies or to attract new ones. Where, as with the Bauer Group, earlier generations had made provisions, there was still room for manoeuvre. But this must be handled carefully because further land acquisition is no longer possible.

Bauer sees it as a classic entrepreneurial task to recognise and seize opportunities. Not only for his own company with its 230 employees but also in the interests of the locations and the people who live and work there. From his point of view a real joint project or teamwork: "If I want to change something, I have to take 
the people and their ideas with me. You can't just wait and see". You can tell in conversation with him that he would find it dishonest if someone were to rant and moan about the conditions, but would consider it beneath themselves to do anything.

If you take a closer look at his company, you understand where this way of thinking comes from. The very slogan of the group of companies specialising in machines and technology signals that theory and practice work well together: "We bring your machines to life!" On the one hand, it is important to keep up to date with technical progress and to allow one's own knowledge to flow into innovative products; on the other hand, it is important to understand what customers need, which tools and processes will make them more successful and where one's own contribution can be made.

Understanding and enthusiasm down to the last detail are required, for example, where components - from one-offs to small series - are manufactured for international customers in the Bauer workshops. These are also required when the company's own know-how is put to good use in contract manufacturing for external and in-house designs, with the spectrum ranging from sub-assemblies to complete machines. The company also sees itself as a specialist in the development and optimisation of manufacturing processes and accompanies the customer's ideas through to series production. In addition to individual components, complete systems and machines are planned and manufactured according to the customer's requirements. This is where performance promises come into play which read like the decathlon plan of a top industrial athlete: "We bring prototypes up to series production readiness and handle the complete process management. Our services also include acceptance, certification and commissioning. Our product portfolio includes machine tools, transport systems, handling systems and many other production machines and assemblies".

The two other business lines also deal with highly technical topics. "Motoren Bauer" sees itself as a service centre for engines and vehicles and offers a comprehensive range of services in the areas of vehicle and engine service, as well as the sale of engines and spare parts. In its own workshop, vehicles of all kinds are repaired-from passenger cars, vans and motor homes to a wide variety of commercial vehicles and buses. BTS GmbH, in turn, is one of the leading suppliers of exhaust gas turbochargers on the independent aftermarket and carries new and replacement turbochargers for all applications and all brands. In addition to turbochargers for cars, trucks, construction machinery, industry, agriculture, sport and tuning, BTS also supplies complete mounting and assembly kits. The latest technologies are used within the Bauer Group. In the field of re-manufacturing, for example, BTS benefits from the distinct professional-industrial standard of the production process as well as from state-of-the-art machinery. The Bauer Group also relies on the latest technologies in areas such as IT and communication, thus creating an optimal working environment for the parts trade of BTS. 
At Bauer, precision and an understanding of detail are not only important to our external business partners but also to our own company. As an entrepreneur, he is a role model, he argues. "Our company was one of the first to fit energy insulation to its halls. This was a signal that environmental protection is a high priority for us and that we actively embrace corresponding innovations and further developments", he cites an example. "Fortunately, this renovation also reduced energy costs by $30 \%$ ".

Communicating such successes is part of the role model function that he plays at the local level - through his involvement in the Weilheim Entrepreneurial Circlewhich he also incorporates in his voluntary work at the Chamber of Commerce and Industry. Bauer is a member of the CCI general assembly, chairman of the Weilheim-Schongau regional committee. "Sustainability is a fundamental topic for our economy. I have to deal with that. If I come up with something on this, I share it with other companies". Although he admits that he has had little time for this in the past. With the regulated succession, however, he now has "more room" for this task again - plus the far-sightedness and experience of decades of entrepreneurial life.

Conversely, he not only passes on information, but is also on the receiving end. "I give and I take". Every event that he attends, "I see as my personal further education". Especially the CCI, with its direct access to knowledge about current political and global events, proves to be a useful source time and again, when the individual entrepreneur is told in the course of time: "Come up with something".

\section{Box: Bauer Unternehmensgruppe GmbH \& Co. KG}

The family-owned company with headquarters in Weilheim has three service areas: Bauer Maschinen und Technologie $\mathrm{GmbH} \&$ Co. KG is a system partner for the complete production and assembly of machines and components. Motoren Bauer GmbH \& Co. KG specialises in the field of vehicle and engine service and spare parts sales. The third pillar, BTS GmbH, is one of the leading suppliers of exhaust gas turbochargers in the independent spare parts market. The company employs 220 people.

CCI commitment: Klaus Bauer is a member of the CCI general assembly and chairman of the CCI regional committee Weilheim-Schongau. 


\section{Portrait 2: Ingrid Obermeier-Osl, Franz Obermeier GmbH- Taking Over a Family Business and Growing in Line with the Spirit of the Times}

\section{Ingrid Obermeier-Osl, Photo Credit: CCI for Munich and Upper Bavaria/Goran Gajanin_Das Kraftbild}

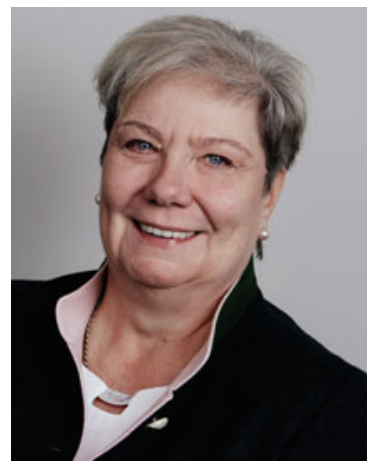

"Volunteering for the economy is in my blood". Ingrid Obermeier-Osl's answer as to how she came to the CCI sounds, at first pass, like a sober statement. Anyone who thinks they can interpret this authentic statement in any other way should listen to a tape recording of the sentence over and over again and would not be able to determine anything else. The businesswoman from Schwindegg in the district of Mühldorf is not someone who leaves things hidden between the lines or adds a certain undertone to a statement. She is like the tree, the forest, which provides her with the material for her company: upright, resilient, straightforward and genuine. She develops her full effect in connection with a task or a longer conversation. That's where each branch of the conversation, each branch of the discussion gets its deeper meaning in the larger context.

"I have taken over the family business", as Ingrid Obermeier-Osl makes it clear to her counterpart, does not act out of inevitability. This sentence tells of entering into responsibility, of accepting a task. This also gives the next sentence its significance. "My father was active in the honorary office of the CCI, I am an entrepreneurial child and like to be active for the companies in the CCI". She knows that an institution based on volunteering is always looking for volunteers who do not see participation as a pastime but as an expression of their entrepreneurship. Doing something, shaping something, not accepting that things remain as they are or even deteriorate because nobody cares is the attitude of an Ingrid Obermeier-Osl. 
When her father was still holding the company's management function in his hands, she was already envisaging herself in the role of future successor. She recognised the benefits of a network long before the term took on its current interpersonal meaning. She understood that although she could take over the business one day, she would not automatically enjoy the connections that would allow the business to thrive. Because she assumes that not only she but also other successors, feel the same way, she founded the Junior Chamber in her home region in December 1982. "This is a network without a background" she says, "a community of responsibility for the good of our location, our community". Nepotism in the sense of "If you help me, I'll help you" is abhorrent to her and especially to people who only want to use these networks for business contacts. "Business can happen all by itself in networks" is her credo.

Long-term interest rates instead of quick returns. This is someone who has sustainability in her blood. No wonder - the timber industry once founded this principle, and it still lives by and from it today. The entrepreneur sums up the result in one sentence: "The friendships of that time have often lasted until today". Some of those who were active with her at that time in the Junior Chamber of Commerce (JCI International) are now involved with her in the Altötting-Mühldorf CCI regional committee. This is a good example of how volunteer work can have an impact on interpersonal relationships for decades.

The other side of Ingrid Obermeier-Osl shows itself where the family business is concerned. Here, the proximity to the material wood is unmistakable. The deeply rooted type with the annual rings of what has been experienced and endured. The unceasing transformation of the elements. The organic growth. The power of the individual tree and the strength of a forest. Wherever you leaf through the imaginary chronicle of Franz Obermeier $\mathrm{GmbH}$, you will find evidence of this: wood shapes the business through and through.

The development and change that the company undergoes is also similar to that in an ecosystem. First of all, the sawmill, built in the founder's hometown $60 \mathrm{~km}$ east of Munich with a view to utilising expansion options and where, originally, mainly spruce roof trusses were produced to support the constant growth in Munich. Then came the next stage, when industrial processing was added to the supply of raw materials, and hardwood was now used to produce frames for the upholstered furniture manufacturer Himolla. And at the other end, thanks to professional thinking and acting, the underlying business grows and the first exports of sawn timber are realised to companies in Europe. Then, over time, the simple supplier becomes increasingly competent; in addition to frame construction, the timber mill also takes on logistical tasks. In addition to new production and storage facilities, shipping is also optimised so that the finished racks can be delivered directly to the customer's production facility. 
A life's work for an entrepreneur who nevertheless ensures early on that the young seedlings can mature in the family forest. Daughter Ingrid and son-in-law Georg Osl acquired their first experiences in the company at the end of the 1980s and from then on supported the company founders.

Then, shortly after German reunification, came the next evolutionary leap for the Obermeiers. The regional brickworks and the chemical industry require a growing number of disposable wooden pallets, which are now produced mechanically in large quantities from coniferous wood in the timber plant. At the same time, in view of economic fluctuations and the dawning globalisation, the realisation was beginning to take hold that the future belongs to product diversity - and entrepreneurial thinking to an even higher degree of innovation. The first solid wood panels for the German furniture industry in beech were produced in Schwindegg. This was a completely new sales market, but it also required ongoing investment in machinery and associated in-house energy generation, as well as capacity expansions in the area of timber drying.

It was at this point when Ingrid Obermeier-Osl noticed two things for herself. Firstly: "You can stay true to established ways and adapt to the times. But you don't always have to change everything to keep up with business". Second: "As an entrepreneur, I have to be authentic. I have to go through life both straight and upright. Even though not everyone may like what I do, everyone knows where they stand". Before "HR" and "Employee Development" become management tasks, the young entrepreneur embraced the human factor in her company.

It is the moment in the conversation when one becomes aware of the paradoxes of this biography: Ingrid Obermeier-Osl is the best example of how it is not the quota that puts a woman in a management position. At the same time, however, she provides plenty of evidence that a mandatory opening of male-dominated executive floors for more female power is beneficial to the economy.

The way she deals with the issue of training alone. It is not only the owner of a company who is concerned about the next generation of skilled workers. There is also someone who is concerned about the existential worries of a family that wants to ensure an adequate future for their children — but has difficulty doing so. It is thanks to Ingrid Obermeier-Osl that for some years now a "vocational education train", the "CCI Education Express" in November, has been travelling through the districts of Mühldorf and Altötting to Salzburg, which the local CCI regional committee has put into operation. When you talk to her about it, a smile beams across her face. "It was worth every effort to implement this". Creating an environment in which young people find it easier to overcome their shyness and insecurity about career orientation - everyone benefits from this. Even the clever "pusher" has learned something for herself: "Training gives you many opportunities to make a difference. Even to leave well-trodden paths and break up outdated structures. 
But Ingrid Obermeier-Osl makes no secret of the fact that she still sees herself "in training" to become a boss and entrepreneur: "I learn from practice every day" she says, referring to the immigrants who have recently come to Germany, including in her company. "It is my job as an entrepreneur to educate these people about our social system, for example. It is completely foreign to them and there is no school where they could learn it more effectively. Except in our company".

She likes to share such insights with others. In the local community council, where she still participates and helps shape the future. On the supervisory board of Kreiskliniken $\mathrm{GmbH}$, where she looks at hospital policy from an economic point of view. And in the Chamber of Commerce and Industry, where she contributes a good proportion of her time to the regional committee, as a member of the general assembly and vice president, and as chairperson of the working group "Women in Business". "It all comes down to a measured approach" she says about the share of voluntary work while being an entrepreneur. "You have to do the tasks you set yourself properly and with passion".

Ingrid Obermeier-Osl - the economy in Upper Bavaria has found someone who leaves a real mark.

\section{Box: Franz Obermeier GmbH}

Franz Obermeier GmbH in Schwindegg is one of the leading wood processing companies in Germany with an annual capacity of 60,000 solid cubic metres of hardwood lumber or 20,000 solid cubic metres of softwood lumber from regional, PEFC-certified stocks. The company was founded in 1956 and has 185 employees. Its range of services includes industrial production for premium furniture manufacturers in Europe and for craftsmen, as well as wooden pallets for industry.

CCI commitment: Ingrid Obermeier-Osl is Vice President of the CCI Munich and Upper Bavaria, Chairwoman of the CCI Regional Committee Altötting-Mühldorf and Chairwoman of the CCI working group "Women in Business". 


\section{Portrait 3: Dr. Eberhard Sasse, Dr. Sasse AG_-Showing Attitude: "Responsibility has Many Facets, but Only One Face: The Entrepreneur".}

\section{Dr. Eberhard Sasse, Photo Credit: CCI for Munich and Upper Bavaria/Goran Gajanin_Das Kraftbild}

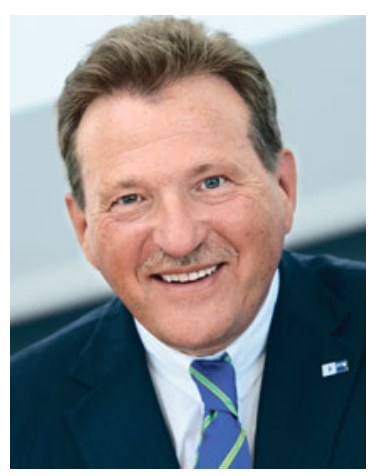

In his mid-20 s, a young man sets up his own business in Munich. He has just finished his studies there. The rebellious atmosphere of the late 1960s has rubbed off on him. Even though he later refers to himself as a "young-spirited sixty-eight-year-old", he thinks nothing of manorial hierarchies, of bullying, and in the end, of state paternalism. Nothing at all. He gets his source of guidance on how entrepreneurship should look like mainly from friends. A few bankers and entrepreneurs also enjoy his attention. Nevertheless: Eberhard Sasse's business plan consists of "trial and error".

He also brings a little experience with him. During his studies he sold ice cream (successfully) and Christmas trees (unsuccessfully). The opportunity was favourable, both times, but the market only once. In the long run neither commitment led to the "big time", so to speak. His main concern was to earn money during his studies.

The next step, with a doctorate in political science in his pocket, leads to a more professional path. In 1976, Sasse took his first step into facility management and founded his own company. A handful of employees work there, he is an entrepreneur, even though he still doesn't want to be part of the establishment. He meets like-minded people in the association of entrepreneurs - and together with them he is dissatisfied with what they offer him. The association lives from contributions and sponsors who try to acquire new business at events. "The logo of the bank at a seminar or training session was more important than the exchange of experiences among themselves", Sasse remembers. "That had no future for me".

But the future had become more serious for his own cause. "The growth of the company made me go from bad guy to good", he recalled. The arc of life takes a turn, the institutions are no longer cloaked in horror. At least one of them: "It was at 
this point that I began to deal with the Chamber of Commerce and Industry. And I could see that the legislator had set up its role and task quite well", he says in retrospect. What he particularly liked was that a small company had as much of a voice as a big one. But that the contributions were levied according to performance and size.

The deeper Sasse looked into the principle of the CCI, the more convinced he was of its structure and work. When it comes to organising and supporting vocational training, for example, he quickly comes to the conclusion that much higher funding would be necessary if this were in the hands of the state. "An organisation supported by active entrepreneurs thinks differently about efficiency and the use of funds. You can see that in every nook and cranny", he says in his analysis. He arrives at exactly the same assessment when it comes to the topic of "self-governance".

What impresses him most, however, is the performance of the CCI as a "think tank" that acts without outside influence and yet delivers affordable services. He also takes careful note of the intensive cooperation between the primary employees and the representatives of the voluntary sector. He makes extensive use of the opportunities because in the meantime the Sasse company has become a fast-growing provider of facility management. Comprehensive knowledge of the location and industry, as well as access to independent information and market analysis, innovations and technologies, are a hard currency for his business decisions and expansion plans. "This was a massive, well-founded information resource", he says, with a gap of roughly four decades.

For him, being independent is more than a principle. It is a matter of course. When asked how he balances work and family, Sasse likes to compare life to a traditional, hand-stitched leather football. Its shell consists of many individual patches "and depending on which of these patches he is falling on, some are in view and some are not". In any case, it's all about keeping the ball in play-and Sasse's football is not just about landing in the back of the business net. So he starts looking for a partner, finds her, makes plans for a family together with her- " "and suddenly you're in charge of a second company, have to divide your attention between two tasks and your strength, too".

The lesson he draws for himself and shares with others from this transformed entrepreneurship is: "Don't make any lazy compromises". His own family makes him - a person who has felt so close to his employees from the very beginningeven more open to social concerns, as they are anchored in the model of the honourable merchant. Not only does he have to provide work for the employees entrusted to him, he also has to ensure that they are well looked after in their environment and that their livelihood is secure. At a booming, highly attractive location like Munich, this is no trivial challenge when you are in a sector that has many employees in the low-wage sector. The work force is existential for 
Dr. Sasse AG, but their own existence suffers from the high cost of living at the place of work. Much earlier on than many other companies, Eberhard Sasse becomes an advocate of the minimum wage in order to provide his people with a livelihood and to give his company a competitive edge.

Wife Christine plays a key role in Sasse's understanding of a family business. She is a partner at eye level, an entrepreneur with her own profile and style - and a co-executive director in the AG. What both share is an understanding of being an entrepreneur and the values associated with it. The fact that they also exemplify these at home lays the foundation for the daughters to become familiar with what it means to be an entrepreneur from an early age. "In our children's reactions to rules and values, we not only recognise the influence we have on them. It is also an expression of our credibility", says Sasse. "Now replace the word 'children' with 'employees' or 'business partners' - and you will recognise a central element of thriving together". In practical terms, this means that the head of the company can confidently take a hand in many facility management activities and that the future bosses have spent a few months working in the regular teams at airports and bus stations. "Voluntarily" as the father points out. After all, succession was a wish, but not an order placed on their daughters.

This essentially corresponds to the fundamental attitude of the philosopher whose ideas for Eberhard Sasse were always, and still are, guidelines for entrepreneurial behaviour within the framework of a state apparatus: Adam Smith. Entrepreneurs built something that should last for a long time and not only provide good balance sheets in the short term; his independence thus became the motor of society and all its members. That is why, following Smith, he sees the greatest possible individual freedom of movement and design within a stable and reliable framework as a desirable ideal state of affairs - and also recognises it in the self-image of a modern chamber of commerce and industry: "We should be able to rely on one another".

This ultimately answers the question of why he volunteers. Finally, the support he received from the $\mathrm{CCI}$ reinforces his understanding of independence: "If you want changes, then take matters into your own hands. Otherwise others will change it for you". Initially as a commercial judge, and later as an elected member of the general assembly at the Chamber of Commerce and Industry, he devotes a good part of his time to the service of the community and society. "We must not only demand and make demands. If you recognise that an institution is good and useful and allows one to collaborate there, then you should also get involved". Especially since the extensive support provided by the primary office provides a solid basis for the volunteer entrepreneurs to be productive: "We can thus carry out our tasks and initiate changes". 
With a good 6,000 employees in 40 branches and an extensive presence in other European countries, Dr. Sasse AG is today "one of the small players among the large multi-service providers" in facility management. It faces up to the change in the industries it serves, from local transport to aviation, from industrial production to real estate, with the typical advantages of an agile unit with flat structures and with an inner readiness for change, including digitalisation as the most prominent factor at present.

Sasse is well aware that the predicate of a family business itself is being put to the test. He argues that in no family will things be the same tomorrow as they are today. "The common origin connects individuals over generations, but it does not force them to leave everything as it was. If we look at Queen Elizabeth and Prince Harry, we understand what that looks like", he cites as an example. "In our company, too, several generations live under one roof, both in leadership and in teams. We talk to each other, exchange experiences, learn from each other, marvel and admire each other - and are as close to life as you can get. Where elsewhere powerful hierarchies are at work, the family business has short communication and decision-making channels. Where others have to get their ideas and impulses from outside, they grow from within the family business. "We do not change because we have to, but because we can and want to. That makes the difference. And that's why family businesses are much more modern than some people think".

\section{Box: Dr. Sasse AG}

Sasse Group is an internationally active family business and one of the leading German facility management providers. Founded in 1976, the Group of companies has its headquarters in Munich. As a family business, Dr. Sasse AG is primarily concerned with personal responsibility for employees, customers and partners. With its name, the Sasse family stands for the high quality of services and for a responsible, people-oriented management style. It exemplifies an understanding of closeness and mindfulness, which permeates the entire company. The company employs about 6,000 people.

CCI commitment: Dr. Eberhard Sasse is President of the Chamber of Commerce and Industry for Munich and Upper Bavaria and President of the Association of Bavarian Chambers of Commerce and Industry (september 2013-june 2021). 


\title{
Portrait 4: Michael Steinbauer, Deutsche DOKA Schalungstechnik GmbH-Working for the Economy in a Strong Community
}

\author{
Michael Steinbauer, Photo Credit: CCI for Munich and Upper Bavaria/Goran \\ Gajanin_Das Kraftbild
}

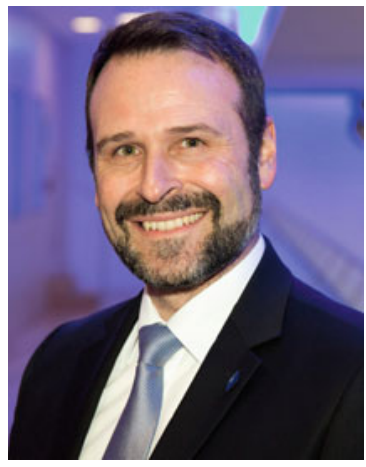

When in 150 years a small carpentry company becomes a globally operating shuttering company, then more than time and the market has changed. Then, over several generations, a changing understanding of technology and strategy, of customer partners and employees, of competence and responsibility will have left its mark and ensured lasting change. This is roughly a summary of what makes up the Austrian "Umdasch Group", which is represented in Germany by the subsidiary Deutsche DOKA Schalungstechnik GmbH, based in Maisach, to the west of Munich.

The abbreviation stands for "DOnauKrAftwerk". For such a plant, which was built in 1954 in Ybbs, Austria, wooden planks were required. These were supplied by the Umdasch Group. The carpenters on the building site joined these together to form large panels. And because this was laborious in the long run, the building contractor for the power station ordered large-area wooden boards - and the contract was won for the delivery. A new product was born. At first still connected with claw dowels, and later glued. In any case, a small revolution in the construction industry.

A classic example, therefore, for the emergence of a hidden champion in medium-sized companies, as with many other cases in the two neighbouring countries of Austria and Germany. It is also typical that such a family-run company does not move anonymously in the economic and social sphere, but shows itself and assumes responsibility. The German DOKA has appointed an employee to represent the company in the Chamber of Commerce and Industry. Michael Steinbauer is a "specially appointed representative" of his company. This is the legal-formal difference to companies that are owner-managed or where the respective Managing Director takes on a voluntary activity at the $\mathrm{CCI}$ - an external 
difference, therefore. From his inner motives Steinbauer is just as committed to this as anybody else and sees himself as an employee who embraces entrepreneurial thinking.

"I came to the CCI in 2004 through my work as an examiner and was awarded a chairmanship of the examination quite early on", recalls Steinbauer, who is responsible for the personnel and training departments in his company. Examiner means invigilating final examinations for young people who have completed vocational training. "My basic motivation came from the field of dual vocational training, which back then (and still today) I see as a decisive competitive factor in Germany", Steinbauer adds. Nowhere else in the global economy is there a comparable training structure that combines the acquisition of practical knowledge in the company with the acquisition of all the necessary theoretical knowledge by attending vocational schools in tandem. The resulting skilled workers are considered a key factor in the quality claim of "Made in Germany".

"When I nominated our company for the CCI trainer award and we came in third place, the celebration ceremony gave us our first contacts with CCI representatives", Steinbauer reports. The discussions developed into an invitation to work in the CCI regional committee in Fürstenfeldbruck, which he accepted and for which he then stood for election by the members. He was elected to the committee and finally to the position of Chairman: "The exchange between entrepreneurs, the sharing of knowledge under the roof of the CCI - that was a motivator for me because it fits my job description as a personnel developer.

His view of the work of the CCI, as well as his own commitment, is shaped by what has developed from this start since then. First of all, there is the topic of regionalisation with which the $\mathrm{CCI}$ has strengthened its impact and presence in parts of Upper Bavaria. As Chairman of the regional committee, Steinbauer was one of the strongest supporters and a driving force in its reorientation. Proximity to the customer, i.e. the members, and stepping out of the "glass palace" of a centralised organization would have paid off, just like a company. "The local perception of the Chamber of Commerce and Industry has strengthened and changedfrom a compulsory contribution structure to a service partner for entrepreneurs" he summarises.

There has also been progress at the regional level in his own environment, which stands for a "new" CCI - and which gives more weight to his core topic of "dual vocational training": "The honouring of examiners for their voluntary work is not a compulsory event, but a genuine expression of appreciation, which thus also receives the publicity it deserves". The same applies to the festive setting for trainee graduation ceremonies, to which keynote speakers are regularly invited. "This is the form of appreciation that we cultivate in the companies' personnel development, in order to increase our attractiveness as an employer, and this also fits in with the CCI's approach to volunteering. 
Steinbauer, who is also a member of the CCI general assembly, also estimates the benefits that the CCI brings to the day-to-day work in the company to be significantly higher in comparison to the past 15 years. "The principle of dealing with (and passing on) topics step by step has proven its worth: from the individual entrepreneur via the regional committee to the general assembly". The knowledge gathered from the individual companies, sectors and regions is combined with the ability of the CCI as an organisation to recognise political signals early on. This cooperation provides the basis for adapting to changes and new challenges in good time, for example in trade agreements or the so-called "diesel city" issue. In such cases, the trust placed in the CCI because of its party-political neutrality proves to be an advantage for all companies - which would never be able to do this on their own.

Steinbauer, who is in agreement with the owners of his company in this respect, intends to continue his voluntary commitment to the CCI to the best of his ability. "The cost of working in the regional committee, in the committees and in working groups such as 'School \& Business' is manageable and can be planned", he says. With pressing issues such as the problem of a shortage of skilled workers, the provision of affordable housing, digitalisation or de-bureaucratisation, there are a lot of tasks that require a strong business community. A community which, as is the case with the CCI, takes on sovereign tasks. This makes sense because experience has shown that "if the state were to take over, taxes would be due and implementation would be more expensive".

\section{Box: Deutsche DOKA Schalungstechnik GmbH}

Doka is one of the world's leading manufacturers of formwork and scaffolding. Doka's range of products and services extends from civil engineering to bridge building, tunnel construction, infrastructure construction and high-rise construction. The company employs a workforce of 6700 people at 160 locations in 70 countries across five continents.

CCI commitment: Michael Steinbauer is a member of the CCI general assembly and Chairman of the Fürstenfeldbruck regional committee. 


\title{
Portrait 5: Kathrin Wickenhäuser-Egger, Wickenhäuser \& Egger AG-Upholding the Value of Giving and Taking
}

\author{
Kathrin Wickenhäuser-Egger, Photo Credit: CCI for Munich and Upper \\ Bavaria/Goran Gajanin_Das Kraftbild
}

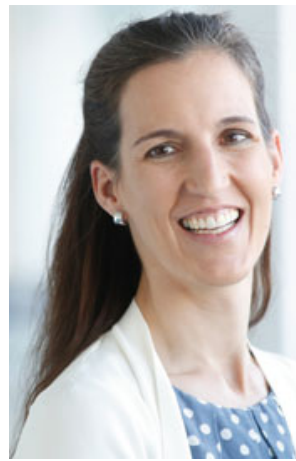

Playing host to others is one thing. Being a successful service provider in a big city is another. Kathrin Wickenhäuser-Egger is aware of the special role she plays as the owner of a traditional, family-run hotel in the centre of Munich. "Our industry is constantly changing. You have to pay careful attention to which proven strategies you can continue to build on - and which innovations and new challenges you can face without hesitation". Only when these basic requirements are met can service and communication with guests reach an appropriate level.

As a tourist hot spot, the Bavarian state capital is in competition with the world's major cities. For many travellers it is one of the "Places you must see before you die", as a bestseller among travel books puts it. But this also means that the Munich market is open - and this openness consciously contributes to the market - to change and transformation in the field of tourism services. Hotel companies, for example, have had to contend for some time now with the fact that "Airbnb", a completely new concept for overnight guests, has claimed a share of the market as a competitor. This disruptive business model not only turns common market mechanisms upside down, it also calls into question the calculations of traditionally operating companies.

What Wickenhäuser-Egger finds disturbing about this and comparable competitors for the preference of travellers: "There is a lack of fair competition. Such providers have so far operated largely in a legal vacuum. What is legally required for commercial inns, B\&Bs and hotels, for example in terms of security measures is not necessary for private providers. This of course allows them to set completely different prices" the entrepreneur gives us as an example. This is one of the reasons, by the way, why she is involved in the honorary office of the Chamber of Commerce and Industry because she sees ways and possibilities to counteract 
undesirable economic and regulatory developments. Not only in her own industry, but "for the economy in general".

The new competition that is emerging is only one aspect among many. Wickenhäuser-Egger, the fourth generation of the family to run the family business, is well aware of this. In her work, she relies not least on the "entrepreneurial gene, which is obviously strongly developed in our company". In 1912, more than 100 years ago, the great-grandmother had taken the economic fate of the family into her own hands and demanded her place in a male-dominated society. By selling motorcycles and cars in Munich, she had followed the spirit and market opportunities of her time - and her own passion. After all, Hilda Wickenhäuser was one of the first female racing drivers for hill climbs in Germany.

In the course of time and over the generations, the entrepreneurial preferences and the family understanding of the economic utility of one's own property changed. Where once chic car bodies waited for their buyers and diligent workshop hands restored the vehicles of their owners, a hotel replaced the car dealership in 1986 by way of family decision. "I grew up with both businesses", says Wickenhäuser-Egger, "and both have fostered my interest in entrepreneurship". The logical consequence: After studying Sociology at the Ludwig-MaximiliansUniversity in Munich, she graduated with a thesis entitled "Success factors for the intergenerational transfer of family businesses". In 2008, she also received her MBA for company founders and successors at the Deggendorf University of Applied Sciences.

After the "transitional years" with renowned hotels such as the Raffles Hotel Vier Jahreszeiten or the Kempinski Hotel Atlantic in Hamburg, her professional career finally began in 2006 at her parents' company-the Cristal Hotel Betriebsgesellschaft mbH. "The hotel doesn't let you go once you've let it catch you", says Wickenhäuser-Egger. "It is an exciting stage with an infinite number of individuals. That's how selling becomes a living world of its own". Working with people, providing services for people, both are close to her heart, "not least because of the daily encounter with cultural circles in all of their facets".

At home, she first started out in the position of Marketing and Sales Manager, then she became Marketing Director. She has been the company's Managing Partner since 2008. When Wickenhäuser \& Egger AG was founded in 2012 to mark the 100th anniversary of the Wickenhäuser family, she and Alexander Egger took over the management of the company. The company portfolio includes the 4-star Hotel Cristal, the 2-star Hotel Dolomit, the 1912 Restaurant \& Bar and the Münchner Stubn, the WE Conference Centre and the CarPark Cristal.

A wide range of services are on offer in a well-structured company, which nevertheless has to prove its right to exist every day. After all, in addition to disruptive competition, other strong market forces also have an impact on the company's own business model. There is, for example, the growing number of boarding houses in Germany that aim for long-term stays and get by with fewer staff than a traditional hotel. There is the search for skilled personnel, which particularly affects the hotel and catering industry with its often strenuous activities and 24/7 service availability. Here, according to Wickenhäuser-Egger, employer 
attractiveness plays a key role, including the "human factor". As a manager, she applies exactly the same criteria in dealing with her employees as she does with her guests: "Saying please and thank you, taking time for a friendly word, showing a moral attitude". The fact that she is committed to the part-time training of junior staff in this context is only logical. "As entrepreneurs, we must always look for best practice and apply it to our needs", she says, "and then put it into practice".

What the young hotel manager also has to deal with is the handling of hotel property. This involves space optimisation and energy-efficient renovation, keeping the catering facilities up to date and flexibly responding to customer wishes with fitness and business needs. On the one hand, there is the location to the south of Munich Central Station - a colourful, lively quarter where you can experience the sight of more than just glitz and glamour. Nonetheless, the family, above all their father Fritz Wickenhäuser, has been committed to this piece of home for many years, he wants to keep the environment of their living and working place attractive and worth living in and uses its extensive network, which also includes the CCI, to this end. Both the father and now the daughter have decided on voluntary work in order to use and serve their location-and thus improve the general conditions, which also benefit their own company.

In general, Kathrin Wickenhäuser-Egger considers her voluntary commitment to play an important role alongside her professional activities. In addition to her office as Vice President of the Chamber of Commerce and Industry for Munich and Upper Bavaria, where she sees education and social issues as her main focus, and Chairperson of the CCI working group on "Corporate Responsibility", she is a Bavarian training ambassador and commercial judge. She contributes her expertise as a member of the Education Committee of the Bavarian Hotel \& Restaurant Association and the Tourism Committee of the Bavarian Economic Advisory Council, as well as the CCI. For locals, she organises district tours in the context of the Munich adult education centre (VHS). She is also a member of the IN VIA Council. This is a Catholic charitable association and a recognised provider of youth welfare services.

Wickenhäuser-Egger is aware of the value of giving and taking. Her own company has also experienced crises in which it was dependent on the help of others. She recalls the economic crisis of 2007/8, in which "tourist markets originating from countries such as the USA collapsed, which are simply existential for our industry". When the SARS crisis (Severe Acute Respiratory Syndrome, an infectious disease) followed shortly afterwards and caused the business to suffer continuously, "we turned our company upside down", she recalls. In retrospect, the exchange with other companies, including companies from outside the industry, was very helpful: "Everyone knows a little bit about something, but in a bundle you get a lot".

At such a time, the CCI proved to be particularly valuable as a platform for communication and knowledge transfer. Which is why they offer their own experience to all those who have doubts as to whether the work and service of the CCI is also useful for them: "When things are going well, you get less involved. When things get tough, you're grateful that you belong". The rejuvenation of the 
committees, the greater diversity of the locations and sectors represented, the increasing liveliness of the discussions, and the (now higher) proportion of women involved - all this shows, in her view, that this insight is gaining ground.

\section{Box: Wickenhäuser \& Egger AG}

The Munich-based company is now in its fourth generation. It includes the 4-star Hotel Cristal and the 2-star Hotel Dolomit. The company also owns the restaurants Münchner Stubn and 1912 Restaurant und Bar, the CarPark Cristal and the WE Conference Centre. Not to forget the innovative stands "Scharf Bude" (used at street festivals), "We love Brez'n" (used at the alternative market Tollwood) or "Brenz'n Kathl” (used at the Oktoberfest).

CCI commitment: Kathrin Wickenhäuser-Egger is Vice President of the CCI for Munich and Upper Bavaria and Chairwoman of the CCI "Corporate Responsibility" Committee.

\section{Portrait 6: Sonja Ziegltrum-Teubner, Bayerische Blumen Zentrale GmbH—Giving Responsibility the Family Name}

\section{Sonja Ziegltrum-Teubner, Photo Credit: CCI for Munich and Upper Bavaria/Goran Gajanin_Das Kraftbild}

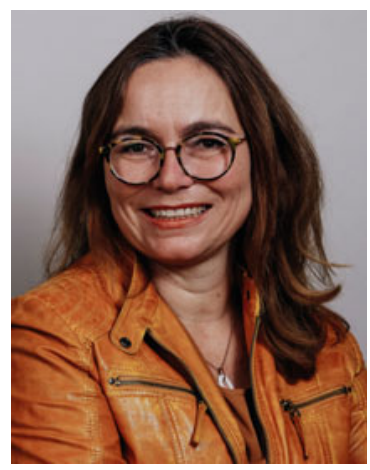

Early in the morning on a country road near Parsdorf, east of Munich a dozen or so vehicles roll along like a string of pearls. All different models and sizes. But if you take a closer look, you see open loading areas, folded back benches, transport boxes. One vehicle after the other now turns off the road, towards a small group of buildings behind a row of trees, in the middle of which is a large hall. "Bayerische Blumen Zentrale" is written on the company sign and the impression deepens that nobody comes here for a small bouquet, but to buy "green" on a large scale. 
This impression is confirmed a few minutes later in a conversation with Sonja Ziegltrum-Teubner. She does not sit down with her visitors in the meeting room, but in the cafeteria, where a beguiling mixture of scents from the world of plants and breakfast delights wafts around the nose. The spark ignites immediately and the message is pleasant: the woman, who is the third generation to run the medium-sized family business, does not claim any privileges. She wants to be right in the middle of the action and let her visiting entourage participate in the atmosphere of the company. Not everything that goes into a company portrait needs to be spoken, printed or presented on PowerPoint pages. The two old ladies pushing a shopping trolley with potted plants past the door, they are just as much a part of it as the man in a work suit who is heaving a pallet of potting soil onto his pickup truck, and the young woman with the stack of cardboard boxes full of decorative material who is turning the corner.

It all started with a market garden in Giesing. That district in the south of the state capital, where Munich is as "Munich-like" as can possibly be imagined. Her grandparents built up the business for a few years until it was destroyed by a bombing raid in the Second World War. The seeds of the next business were then sown outside the city limits, even a little bigger this time. With the increasing saturation of people in the wake of the economic miracle, the first crop rotation in the company took place: instead of vegetables, the Ziegltrums now grew ornamental plants, which continue to grow, as nature intends.

The greatest upheaval came with the handover to the second generation. Production and wholesale were divided into two companies, plus imports for florist supplies. It was part of good manners in Germany in the 1970s to give each other flowers and decorate rooms with fresh flowers bought from the florist of confidence on the next street corner. The catchment area soon expanded beyond Munich and the local district of Ebersberg. To this end, Ziegltrums set flower trucks in motion, the so-called "Flowers on wheels" approach. "To this day, our brand presence has had an effect on a radius of 100 to 150 kilometres", reports Sonja Ziegltrum-Teubner. "That's where we deliver, and from there customers come to us".

Whereby at the beginning of the 21 st century the customer structure is completely different from that up to the year 2000, and the range of products and services offered to commercial customers has become highly concentrated. Large DIY stores have become the competition, and the packaged carnations from discounters are depriving the flower retail trade of its nutrients. This is why Bayerische Blumen Zentrale opened up. The comprehensive range of products, concentrated at large locations, is now also aimed at other commercial customers: Decorators, restaurateurs and hoteliers are now regular customers.

We still rely to a large extent on producing plants ourselves", the entrepreneur makes clear. "We need bulk buyers". These include corporations that often rigorously enforce their terms. She reports on the exchange of information with other producers in the region who have had to endure some hefty experiences with retail chains, for example. "There are annual talks with pressure on the terms. And when someone reminds them that there is now a minimum wage in place, they are told 
under no uncertain terms to sharpen their pencil and raise their game". Under these circumstances, she sometimes wonders whether the sums as a supplier still add up with any benefit at the end of the day. Especially when she has to sign off on "social standards" within the framework of a business relationship, which the buyer then uses to promote his products. "I am annoyed by this double standard. I'm not in favour of fraudulent labelling.

The ideal of the honourable merchant, therefore, means a lot to her, especially in relation to her employees and her own suppliers. "This has always been a guiding principle for me. I want to be able to keep looking at myself in the mirror". In a family business it is anchored in the genes of every single member of the family that one feels committed in the long term and acts accordingly. Social responsibility is given a name, "the name of our family".

As an example of this, she mentions the way in which refugees are treated. In her own company, she says, people were hired from their ranks as soon as possible, "there was no question at all for us". In the meantime, Bayerische Blumen Zentrale is considered a model company in this respect. The boss is valued as a discussion partner in associations, in politics and in the media and is asked for advice. But her experience does not automatically have a knock-on effect. Something that annoys her. Not for her own sake, but because of the refugees. "I can't see why people aren't allowed to work". In the case of the $3+2$ rule, for example-young refugees who took up training for 3 years were then allowed to stay in the company, and thus in the country, for two more years - but bureaucracy soon curbed the idealism of companies. "The SME segment did it because we were happy to be able to fill positions. Then came the disappointment, because politicians obviously didn't intend to go all the way with it".

Whereby the subject of training positions at Ziegltrum-Teubner does not only have a humanitarian angle to it. "One of the serious changes in our industry, but also for many other medium-sized companies, is the lack of young people", says the entrepreneur. "There is too little demand for many professions that involve physical exertion and time spent outdoors". Against this background, the increasing preference for academia in vocational training — "a social phenomenon"-is proving to be a major challenge for companies. Young people only seek their chance in companies when other career paths have proven to be impassable: "These young people are then overqualified for jobs here with us. And they have their first major failure behind them before their professional life has really started". Added to this is the growing mobility of people, the result of which is that the old "learn and stay" principle is dissolving: "The old models are no longer correct".

To this day, in her capacity as Chairwoman of the Ebersberg regional committee of the Chamber of Commerce and Industry but also as a member of the general assembly of the Chamber of Commerce and Industry, she never misses an opportunity to address this topic. There are many such opportunities because "here in the district I am the face of the CCI". The honorary entrepreneur from the 
neighbourhood takes on the role, so to speak, the "foreign office" of the CCI and the primary office, the communication lock in both directions: "I am invited to every event here. I am the closest point of contact people have to the CCI".

In contrast to the party-politically neutral CCI, Ziegltrum-Teubner is also politically involved in her capacity as entrepreneur and citizen. She has already been a member of the local council of her hometown for one term of office. And she has gained the following experience: "As an entrepreneur I am trusted to take on more political responsibility. This is part of the traditional role model, which in their view still needs to be worked on. The same applies to the education gap in the "economy", which is still too large in Germany. Tasks for which she relies on the network within the CCI, both with the volunteers and the primary employees. "The longer I'm there, the more I become aware of how much you can learn" she says, "But: you have to become active yourself".

\section{Box: Bayerische Blumen Zentrale GmbH}

Starting out as a nursery, Bayerische Blumenzentrale in Parsdorf is today a medium-sized company with regional and international production facilities and company-owned imports from all over the world. At present, over 300 employees from Germany (Bavaria), Austria, Hungary and Romania work for the group of companies, which consists of seven wholesale companies and five production companies. Today, a customer can meet the entire range of requirements of the flower, decoration and florist industry at every location.

CCI commitment: Sonja Ziegltrum-Teubner is a member of the CCI general assembly and Chairwoman of the Ebersberg regional committee.

\footnotetext{
Open Access This chapter is licensed under the terms of the Creative Commons Attribution-NonCommercial-NoDerivatives 4.0 International License (http://creativecommons. org/licenses/by-nc-nd/4.0/), which permits any noncommercial use, sharing, distribution and reproduction in any medium or format, as long as you give appropriate credit to the original author (s) and the source, provide a link to the Creative Commons license and indicate if you modified the licensed material. You do not have permission under this license to share adapted material derived from this chapter or parts of it.

The images or other third party material in this chapter are included in the chapter's Creative Commons license, unless indicated otherwise in a credit line to the material. If material is not included in the chapter's Creative Commons license and your intended use is not permitted by statutory regulation or exceeds the permitted use, you will need to obtain permission directly from the copyright holder.
} 